\title{
Afforestation of Transformed Savanna and Resulting Land Cover Change: A Case Study of Zaria (Nigeria)
}

\author{
Ewa E. Kurowska ${ }^{1, *(\mathbb{D})}$, Andrzej Czerniak ${ }^{1}$ (D) and Muhammad Lawal Garba ${ }^{2}$ \\ 1 Department of Forest Engineering, Faculty of Forestry and Wood Technology, Poznan University of Life \\ Sciences, 60-625 Poznan, Poland; andrzej.czerniak@up.poznan.pl \\ 2 Department of Geology, Ahmadu Bello University, Zaria 810107, Nigeria; mlgarba@abu.edu.ng \\ * Correspondence: ewa.kurowska@up.poznan.pl
}

Citation: Kurowska, E.E.; Czerniak, A.; Garba, M.L. Afforestation of Transformed Savanna and Resulting Land Cover Change: A Case Study of Zaria (Nigeria). Sustainability 2022, 14, 1160. https://doi.org/10.3390/ su14031160

Academic Editor: Sharif Ahmed Mukul

Received: 6 November 2021

Accepted: 12 January 2022

Published: 20 January 2022

Publisher's Note: MDPI stays neutral with regard to jurisdictional claims in published maps and institutional affiliations.

Copyright: (C) 2022 by the authors. Licensee MDPI, Basel, Switzerland. This article is an open access article distributed under the terms and conditions of the Creative Commons Attribution (CC BY) license (https:// creativecommons.org/licenses/by/ $4.0 /)$.

\begin{abstract}
This paper presents the effects of actions aiming at tree planting, and thus protection of the land belonging to Ahmadu Bello University (ABU) in Zaria (Nigeria) from erosion. This area is located within the northern limits of the Guinea savanna belt, which has been considerably transformed primarily for agricultural purposes. For years this area has been subjected to the destructive surface and gully erosion processes, which were documented both by field work and the analysis of high-resolution images presented by Google Earth. Land erosion leads to the silting of an impounding reservoir (Kubanni) - the primary water source for the university campus and the basis for its existence. Since 2000, the university has been actively involved in tree-planting efforts in the campus vicinity, executed mainly through the establishment of small plantations ranging in area from approximately 1 ha to 56 ha. Today, these measures have brought tangible effects such as increment of tree-planted expanses, as evidenced in the multitemporal analysis of the Landsat 7 ETM+ and Landsat 8 OLI satellite images. The increasing planted area protects both the soil and the reservoir. A marked stand increment (almost doubled) has been recorded, which is evident from the satellite imageries, and is presented on the land-use map produced with GIS technique for this project.
\end{abstract}

Keywords: transformed savanna; tree cover development; plantations; erosion; land protection; satellite image; GIS

\section{Introduction}

According to data from 2015, the part of Nigeria covered with forests amounts to $6,993,000$ ha $\left(69,930 \mathrm{~km}^{2}\right)$ [1], and the total (land) area of Nigeria is $910,768 \mathrm{~km}^{2}$, which is equivalent to a forest cover index of $7.68 \%$. For many decades, Nigeria has experienced the process of extremely rapid deforestation, as evidenced by the published statistical data (Table 1).

The problems of deforestation and degradation of forested areas stem from large-scale timber harvesting, acquisition of land for agriculture, especially large plantations in the south, farming and grazing in the north of Nigeria, at the expense of natural wooded land. Deforestation, overgrazing, tillage and unsuitable agricultural practices are wellknown causes of accelerated soil erosion processes. This is a problem observed globally, including many African regions [5,6]. In sub-Saharan Africa, particularly in the Sahel, a crucial factor in soil degradation is firewood collection and use; over the last several decades, deforestation or exploitation of wood fuel for domestic purposes or other uses have accounted for over $17 \%$ [7] of soil degradation in that region.

Drought is another factor contributing to the depletion of naturally wooded areas and other natural vegetation zones, thus leading to soil degradation and intensification of erosion processes, particularly in the northern part of Nigeria in the savanna belt, as indicated by experts in their reports on the status of the vegetation cover in the country [8]. Since the Great West African Drought of the 1970s, the northern region of Nigeria has 
been constantly threatened with droughts, particularly at latitudes north of the $12^{\circ}$ parallel. This is a transition zone between the moist regions in the south and the Sahara in the north $[9,10]$. Problems related to climate change have been aggravated in the last two decades due to global climate change and desertification processes affects this region similarly to other African countries [11-13]. In the north of Nigeria, desertification and land resource degradation are attributed to climatic variations, as well as to population increase that causes mismanagement of the land [14-16]. The scale of the vegetation cover changes indicated by research results obtained particularly through remote sensing requires actions aimed at mitigating and preventing further losses in the environment $[17,18]$.

Table 1. The forest cover structure in Nigeria [1-4].

\begin{tabular}{ccccccccc}
\hline Forest Class & $\mathbf{1 9 7 7}$ & $\mathbf{1 9 9 0}$ & $\mathbf{1 9 9 4}$ & $\mathbf{2 0 0 0}$ & $\mathbf{2 0 0 5}$ & $\mathbf{2 0 1 0}$ & $\mathbf{2 0 1 5}$ \\
\cline { 2 - 8 } & & & & Area (1000 ha) & & \\
\hline Primary forest & 2623 & 1556 & 1228 & 736 & 326 & 54 & 20 \\
\hline $\begin{array}{c}\text { Planted forest } \\
\text { (productive plantations) }\end{array}$ & 164 & 251 & 276 & 316 & 349 & 382 & 420 \\
\hline $\begin{array}{c}\text { Other naturally regenerated forest } \\
\text { Total forest }\end{array}$ & 19,772 & 15,427 & 14,090 & 12,085 & 10,414 & 8659 & 6553 \\
\hline $\begin{array}{c}\text { Total forest and other } \\
\text { wooded land }\end{array}$ & not available & 26,559 & 17,234 & 15,594 & 13,137 & 11,089 & 9095 & 6993 \\
\hline
\end{tabular}

For this reason, the Nigerian government willingly joined the international UN initiative referred to as the Great Green Wall. The concept was developed in 2005 during the summit of the Community of Sahel-Saharan States. The aim is to create an expansive, panAfrican vegetation belt. The objective of the Great Green Wall is to stop the desertification of central Africa. As specified in the report on the implementation of the programme in 2020, to date in Nigeria 2801 ha of land has been reforested, and multipurpose gardens have been established on 373 ha [19].

The Great Green Wall is a huge undertaking, but not the only one in Nigeria aiming at tree planting and countering forest losses. The focus is on the establishment of a positive attitude of the local communities to forest resources and to their management. Tree-planting initiatives are implemented both on a greater and smaller scale, with the effects probably still not completely satisfactory, however there are already some successes evident in the natural environment. It seems that in the face of huge losses in forest cover, as well as the overall changes in land cover, any initiative that brings positive effects in the form of an increase in wooded areas is valuable. An example in this respect may be provided by the afforestation actions undertaken for many years now by the authorities and the academic community of Ahmadu Bello University (ABU) in Zaria. These actions and their outcomes are discussed in this paper.

Ahmadu Bello University in Zaria has been dynamically involved in afforestation exercises in the vicinity of its campus and implementing the noble cause of environmental protection and revitalization for years. In view of the tragic statistics and the underlying cause, i.e., the actual deforestation in Nigeria, the activities of the university authorities and the entire academic community vividly illustrate how this negative trend may be averted locally. Moreover, this paper also shows problems faced when implementing tree-planting measures, along with applicable methods to facilitate actions and make them more efficient.

The main objective of the presented survey was to inventory the areas planted with trees in the period from 2000 to 2020, applying methods previously not used for land and resource management at ABU, i.e., GIS and satellite imagery techniques, obviously integrated with a field work in the study area, and as a result, to prepare a map showing the spatial arrangement of afforested areas and other inventoried elements of spatial development of the $\mathrm{ABU}$ land. It was planned to obtain quantitative information on the progress 
in afforestation. It was assumed that the implementation of the results would improve the spatial management system of the university premises, as the land administrators had not had tools such as a detailed digital map (or even a traditional paper map) or a database of the land-use features. In addition, the collected and visualized information on the afforestation and arrangement of other spatial elements in the study area were then used to support the analysis of the effects of erosion and its impact on the viability of the retention reservoir, which is the main source of water for the ABU campus. This information was also used to help to design activities for the protection and revitalization of the reservoir in the future. As the article focuses mainly on the aspect of afforestation, some suggestions were provided concerning innovative planting, tending and protection methods for trees and shrubs-differing from the conventional plantation culture.

\section{Study Area}

\subsection{Location}

The study area consists of the land owned by Ahmadu Bello University in Zaria (ABU), i.e., the main campus together with its vicinity; some research activities also concerned areas outside the ABU territory. The study area is located $12 \mathrm{~km}$ west of the city of Zaria (Kaduna State) (Figure 1), in the northern part of Nigeria, characterized by a tropical savanna climate. The ABU land under study with a total area of about $30.2 \mathrm{~km}^{2}$ (3020 ha) is divided into the well-developed, northern part, covering approximately $0.9 \mathrm{~km}^{2}$ (900 ha), called the main campus and hospital area, i.e., 30\% of the total University area, and the part not used for academic purposes (southern), which is $21.20 \mathrm{~km}^{2}$ (2120 ha) or $70 \%$ of the current total area. The developed part, which may be considered urbanized, comprises the land and buildings used for teaching, administrative and housing purposes, while the undeveloped part comprises farms, wild shrub vegetation, eroded barren land, covering significant part of the catchment of the Kubanni stream flowing in the area. One of the major elements of the natural environment in the study area is the Kubanni impounding reservoir, constructed on the stream in the land belonging to the University.

\subsection{Tree Cover and Environmental Problems}

Zaria is situated in the northern part of the Guinea savanna belt (Figure 1a). In large areas of the northern and central Guinea savanna zone, Isoberlinia doka and other deciduous species predominate, while trees becoming completely free from foliage in the dry season are rare. The natural broad-leaved forest is composed primarily of Annona senegalensis, Vitellaria paradoxa, Cussonia barteri, Daniellia oliveri, Isoberlinia doka, Lannea acida, Monotes kerstingii, Prosopis africana, Terminalia avicennioides and Uapaca togoensis [20]. In the university grounds and in the immediate vicinity, the most popular tree species include Dalbergia sissoo, Gmelina aborea, Khaya senegalensis, Thevetia nerrifoliea, and Azadirachta indica. The campus itself, the other university grounds, farther areas around Zaria, as well as generally most of northern Nigeria, have been considerably transformed (urbanized or adapted to agricultural uses). For this reason, the scarce areas of natural savanna, particularly covered by tree vegetation, and a few forest enclaves, are designated as protected areas. Examples located near Zaria are: Falgore Game Reserve (located $100 \mathrm{~km}$ east of Zaria) and Kwiambana Game Reserve and Kamuku National Park (about $100 \mathrm{~km}$ to the west) where the most common species are Isoberlinia doka and Isoberlinia tomentosa accompanied by Terminalia spp., Daniellia oliveri (in Kwiambana and Kamuku forests) [21,22], Khaya senegalensis, Vitex doniana, Anogeissus leiocarpus, Tamarindus indica, Detarium microcarpum and Pterocarpus erinaceus [17].

In the areas around Zaria with intensive agricultural activity, the most typically found trees are purposefully planted, often useful (e.g., fruit trees) or fast-growing species such as eucalyptus. 


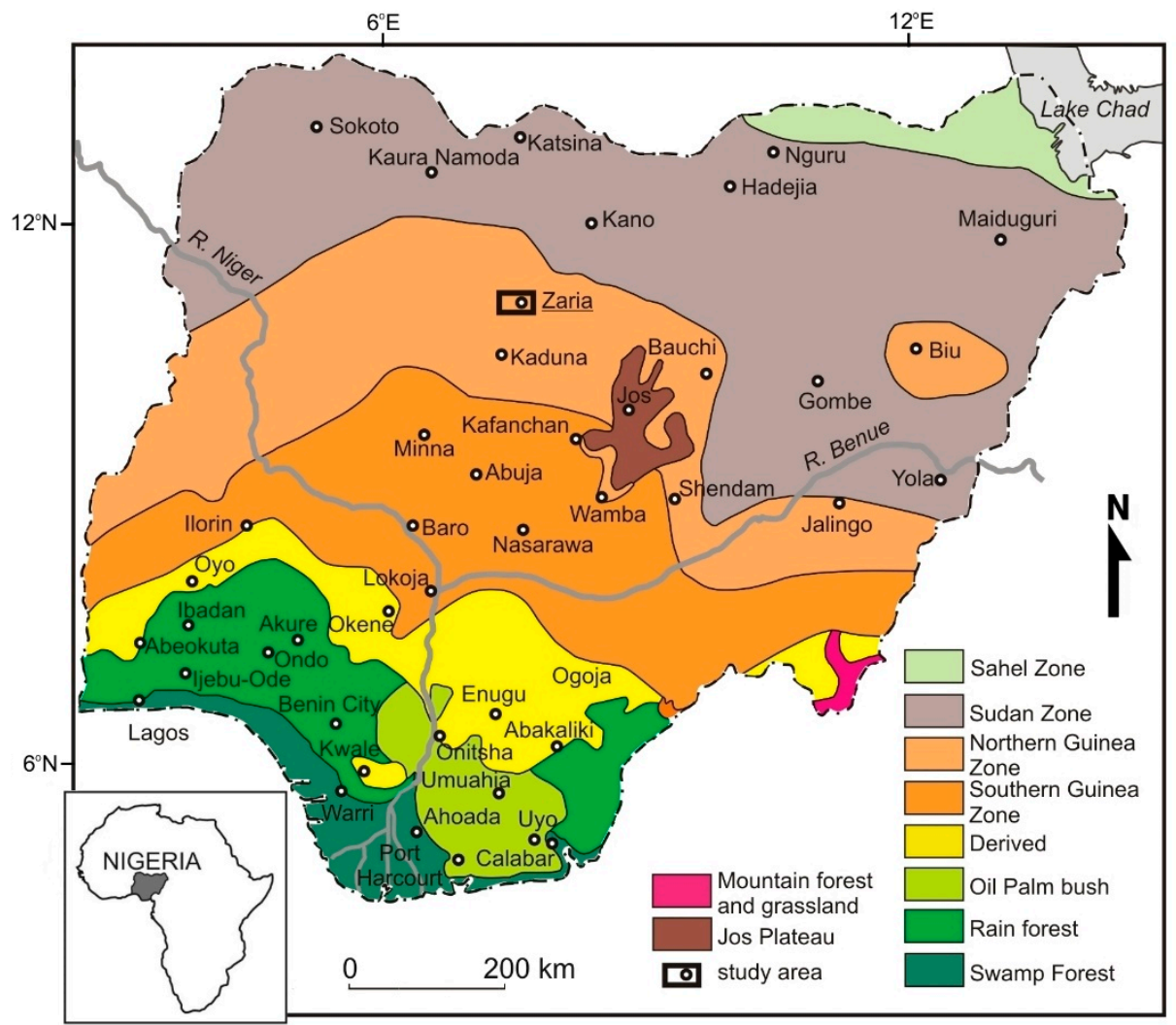

(a)

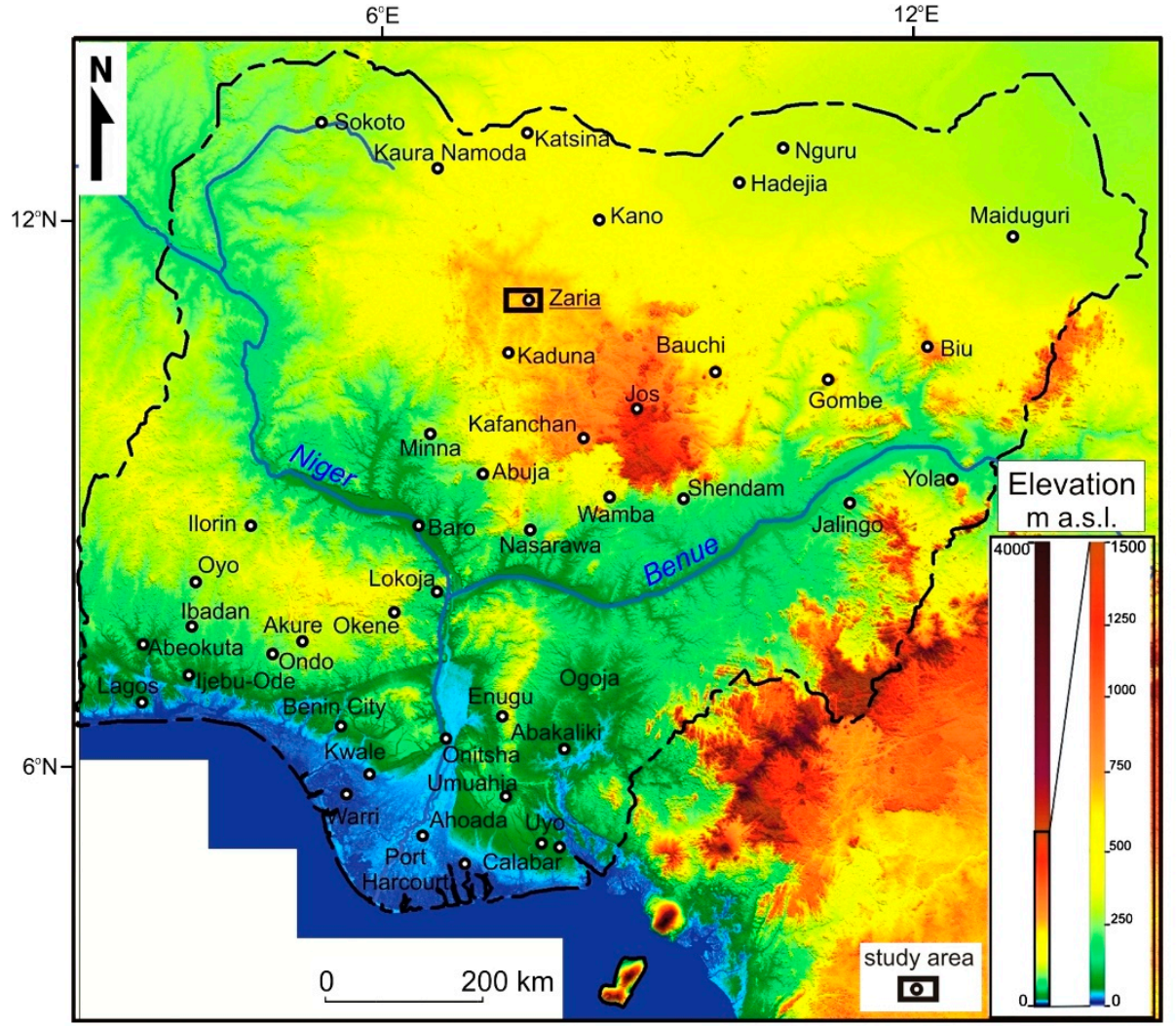

(b)

Figure 1. Location of the study area: (a) on the map showing the distribution of vegetation zones in Nigeria (according to [23] modified), (b) on the Digital Elevation Model (SRTM [24]). 
In 2008, the housing facilities of the campus accommodated approximately 8470 people (ABU employees and their dependents) and 15,242 students staying in hostels. The number of nonresidents (employees and students, hired seasonal workers) was approximately 11,714 . The size of the population related to the campus is of considerable importance for one of the main environmental problems in the area, i.e., provision of a sufficient amount of water and ensuring its adequate quality for the entire institution and the academic community in order to properly operate and serve all their functions. The primary source of water for the campus is provided by the Kubanni reservoir constructed in 1977. Unfortunately, the reservoir has been threatened due to its silting up, which was one of the main problems for the university. Studies conducted in 2008 in order to identify a solution to that problem showed that the clastic material silting the Kubanni reservoir originates from the intensive erosion of the land within the catchment. As a result, the capacity of the reservoir has reduced from its initial $2.6 \times 10^{6} \mathrm{~m}^{3}$ by almost $40 \%$, which was described in the "Report on result of measurement of the remaining storage in Kubanni impounding reservoir and proposal for upgrading the environment in Kubanni drainage basin" [25].

The report concluded that the erosion was initiated as a result of the degradation of the biological environment in the Kubanni catchment area, and this may be slowed down only through environmental revitalization of the catchment. Since the university is not the owner of the entire catchment area, environmental revitalization works were started only in the land owned by the university.

Erosion is a significant problem in the environment of the undeveloped part of the university grounds. It is likely that certain areas were subjected to surface and gully erosion before the campus was established. However, it is supposed that the second half of the 20th century marked the rejuvenation and expansion of the existing as well as the formation of new regions degraded by erosion (Figure 2). This was indirectly related to a rapid increase in the population in this region, which caused an increased demand for food and fuel wood, being a primary energy source used in households, especially in rural and poorly urbanized areas, as well as cities [26,27]. Thus, the increase in the population size is directly connected with deforestation, excessive grazing as well as grassland and shrub burning, which in turn leads to increased surface run-off while reducing infiltration. At present, active erosion areas (bad lands and gullies) cover over $3.3 \mathrm{~km}^{2}$ (330 ha), i.e., approximately $15.6 \%$ of the ABU land.
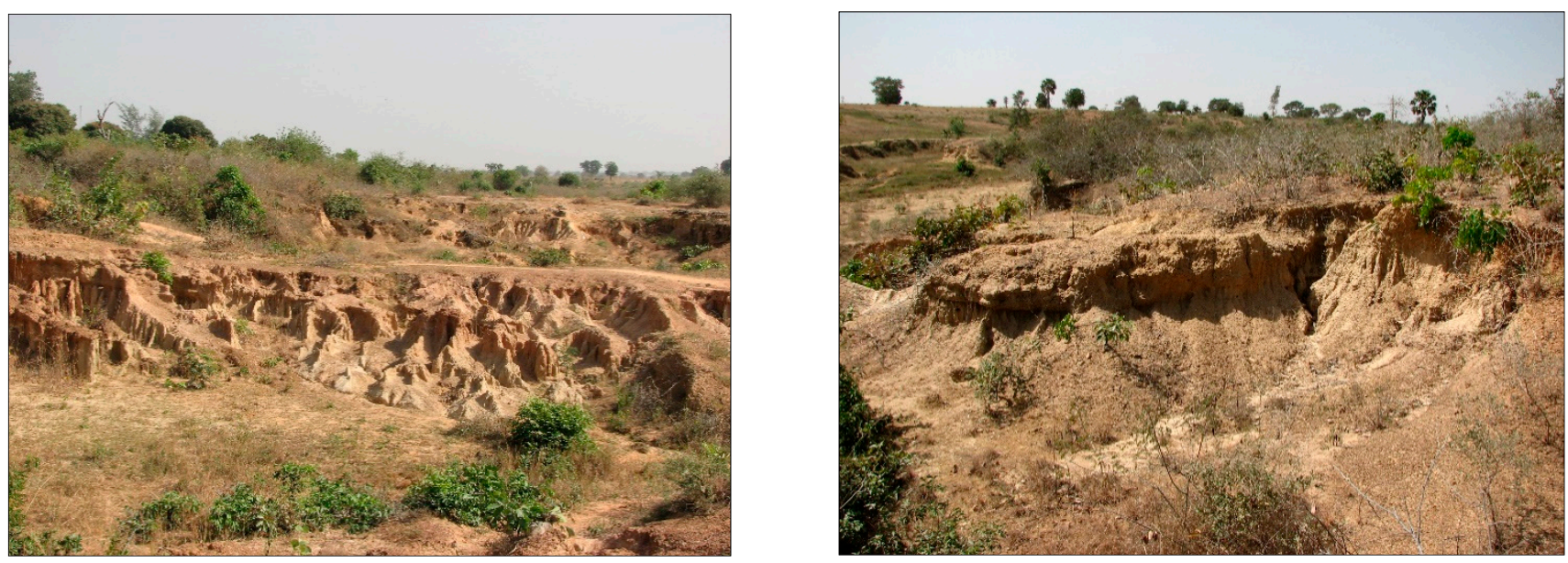

Figure 2. Areas degraded by erosion (bad lands, gully erosion) in ABU-owned land south of the main campus (photos by E.E. Kurowska, 2011).

Almost the entire land in the vicinity of the university was turned into arable fields by local inhabitants of small settlements. As a result of herds grazing, cutting down trees for fuel, soil cultivation and straw burning after harvest of crops, the exposed soil is always subjected to the impact of torrential rains in the early rainy season. Exposed soil undergoes 
physical erosion - the destructive action of rainwater, which transports fine sedimentation material to the lake, as a consequence silting it up. The fine-grained sediments come from the surface layer of regolith-weathered Precambrian crystalline rocks (gneisses and migmatites) that make up the Nigerian Shield. This shield occupies the central part of Nigeria, forming the vast upland where the study area is located (Figure 1b).

Climatic conditions play a key role in the erosion process. In the Zaria region, the rainy season lasts from the end of April to October (Figure 3). August-September are the wettest months of the year, when torrential rains fall and run-off is very high, causing the erosion of the bare soil. During this period, rainfall is typically of short duration, but highly intensive. The rest of the year is the dry season, extending from the end of October to April. There is no precipitation during the dry season. In the course of the year, air temperatures vary. As shown by the mean values from the period of 2000-2005, the minimum temperatures of $15-17^{\circ} \mathrm{C}$ are recorded from November to January (as low as $13.6^{\circ} \mathrm{C}$ reported in December 2005), i.e., in the dry season, while April is the hottest month with temperatures of $38^{\circ} \mathrm{C}$ (Figure 3), exceptionally reaching as much as $40^{\circ} \mathrm{C}$ (according to the Samaru weather station) [28].

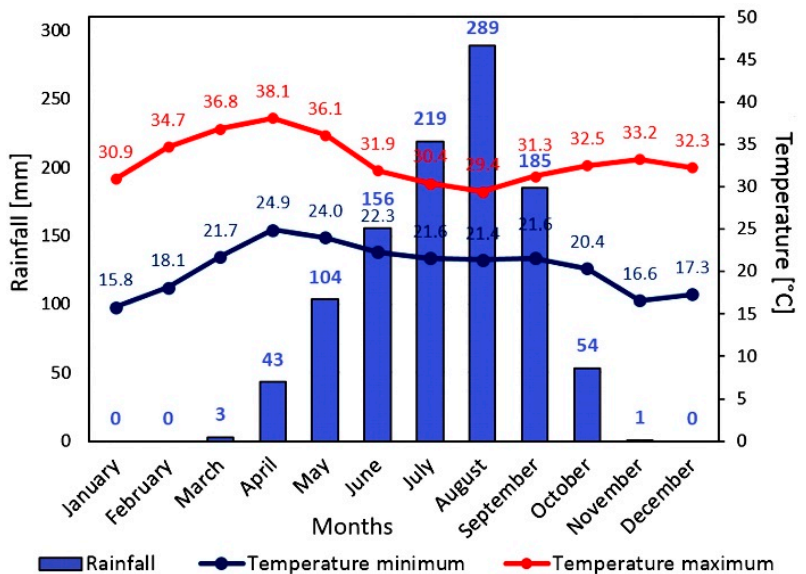

(a)

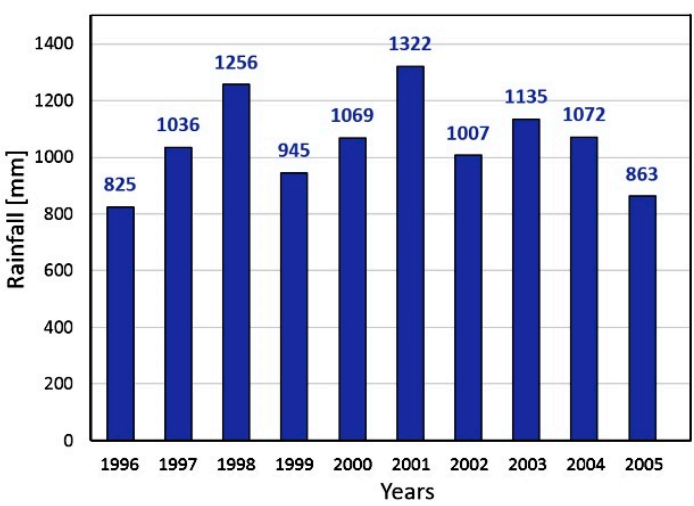

(b)

Figure 3. Characteristics of climate for the Zaria region (data obtained from the Samaru weather station [28]); (a) total monthly rainfall, minimum and maximum temperatures throughout the year (b) mean annual precipitation; the values presented as average for period 1996-2005.

Taking into consideration both natural and anthropogenic conditions, it was predicted that the stability of water supply from the Kubanni reservoir to the university campus at the level of 2008 will be threatened starting from 2022 if no measures countering lake silting are undertaken [25].

To curtail these problems, the university authorities decided to protect relict vegetation and also to plant a tree belt around the impounding reservoir and the campus. This would be a method to save the Kubanni reservoir and the campus against destruction, improve the condition of the environment and make the area more beautiful in general.

Afforestation in this area was initiated at the turn of the 21st century. In this way, tree-planting operations started in the parts of the land located closest to the developed part of the university and certain parts of the erosion-affected land.

\section{Materials and Methods}

In 2008, a survey was conducted to study the status of the vegetation cover and the condition of the natural environment in the immediate and farther vicinity of Kubanni lake. It was assumed that the growth of tree cover in the considered period (2000-2020) can be quantified, for which the GIS method and satellite images with a useful resolution were used. In the study area, no large-scale maps were available before, which would show the location of objects, the condition of the environment and spatial development of the 
area. The first step in this study was to create such a map on the basis of a high-resolution satellite image. Then, the surface increment of the tree cover was also analysed with the help of Landsat images. All the observations, data and data processing products were used to interpret and specify certain conclusions and recommendations.

\subsection{Field Work}

Field works comprised surveys of selected natural environment elements in the study area (vegetation cover, surface water, erosion manifestations), the status of the Kubanni impounding reservoir, land-use categories, as well as cartographic works aiming at the preparation of an environmental map of the area. The field surveys were conducted in January 2008 and were supported with Earth observation records of the region obtained during 2007-2009.

\subsection{Land-Use Map}

Both for the field work and desk studies on the environmental map, the satellite images available on Google Earth (Quickbird or GeoEye by DigitalGLobe/Maxar Technology; Location: Westminster, CO, USA) [29] were used in 2008. Due to their very high spatial resolution: $0.6 \mathrm{~m}$ and $2.4 \mathrm{~m}$ (Quickbird), $0.41 \mathrm{~m}$ and $1.65 \mathrm{~m}$ (GeoEye-1), they are suitable for detailed land cover mapping, providing clear and sharp view of the elements of land cover including even single trees and their spatial arrangement. A total of 118 image tiles covering study area were imported from Google Earth into GIS software and georeferenced to the Universal Transverse Mercator (UTM) zone 32 to create one single image. The tree-planting sectors, badlands and developed university districts were then manually digitized. The image was applied as the base map for survey works and for the preparation of the land-use map; the entire material combined with the data obtained in the field was elaborated using MapInfo 7.5 and QuantumGIS 2.18 software.

Then, the Google Earth image of the study area was analysed again, but this time the image represented the land cover of 2020. The land-use map created several years earlier was supplemented by marking the areas of new tree plantings (plantations) established after 2008 and currently clearly visible on the high-resolution satellite image.

The map became a tool used to solve the key environmental problem concerning the viability of the main water source in the area, i.e., the Kubanni reservoir. It also gave an idea (quantitatively) about spatial relationship between elements of the environment.

\subsection{Estimation of Vegetation Cover from Landsat Images}

The Google Earth satellite image and the land-use map produced on its basis for the university in Zaria reflected the status of the environment in 2008, whereas actions to protect the land around the campus and the Kubanni reservoir were initiated as early as around the year 2000. These activities consisted primarily of tree plantings in the form of small plantations in several areas distributed at small distances from one another. In order to illustrate a comparison of the effects of tree plantings, the Landsat 7 ETM+ and Landsat 8 OLI satellite datasets at $30 \mathrm{~m}$ resolution were used, forming colour images, particularly suitable for the analysis of vegetation cover. Data were made available by United States Geological Survey [30]. The images downloaded from the USGS platform were already georeferenced to the Universal Transverse Mercator coordinate system zone 32, and processed with the Level 1 Product Generation System (LPGS), Standard Terrain Correction (L1TP), which means they were radiometrically calibrated and orthorectified. Then, the large scenes were clipped to the area of interest (ABU territory). The appropriate separate bands (green, red and near infrared) were converted into reflectance, and the atmospheric correction was applied. The Landsat 7 band set consisted of bands 4, 3, 2 and Landsat 8-bands 5, 4, 3. Finally, the band sets were combined to produce the falsecolour composites that highlight the presence of vegetation coverage. This was followed by the vegetation indices calculation: Normalized Difference Vegetation Index (NDVI), Atmospherically Resistant Vegetation Index (ARVI) and Modified Triangular Vegetation 
Index 2 (MTVI2). A simple threshold classification was applied to images of 2000 and 2020, and finally the surface area covered by vegetation in the study area was estimated.

Research on temporal and spatial patterns of vegetation cover based on methods using solar radiation reflected by vegetation at certain wavelength ranges, particularly the red and infrared channels, is widely used (these are two bands sensitive to the presence of chlorophyll in reflective/absorptive matter) and provides invaluable spatial information. Practically, the spectral reflectance effects are usually presented as vegetation indexes, including analyses of NDVI (Equation (1) [31])—one of the basic signs for presence and condition of vegetation as it is correlated with absorbed photosynthetically active radiation and vegetation primary production [31-33]. This method is readily used in studies on the variability and condition of vegetation cover in Africa and Nigeria [17,34,35]. The other, more advanced vegetation indices also used in this study to validate the NDVI results were: ARVI and MTVI2 (Equations (2) and (3) $[36,37])$, which are based on the red and near-infrared bands that detect chlorophyll, but are also sensitive to soil reflectance properties and atmospheric effects [36-38].

$$
\begin{gathered}
\mathrm{NDVI}=(\mathrm{NIR}-\mathrm{RED}) /(\mathrm{NIR}+\mathrm{RED}) \\
\mathrm{ARVI}=(\mathrm{NIR}-\mathrm{rb}) /(\mathrm{NIR}+\mathrm{rb}) \\
\text { where } \mathrm{rb}=\mathrm{RED}-\gamma \times(\mathrm{BLUE}-\mathrm{RED}) ; \gamma=1 \\
\operatorname{MTVI2}=\frac{1.5 \times(1.2 \times(\mathrm{NIR}-\mathrm{GREEN})-2.5 \times(\mathrm{RED}-\mathrm{GREEN}))}{\sqrt{(2 \times \mathrm{NIR}+1)^{2}-(6 \times \mathrm{NIR}-5 \times \sqrt{\mathrm{RED}})}-0.5}
\end{gathered}
$$

BLUE, GREEN, RED, NIR-near-infrared-spectral ranges.

In the present study, operations on Landsat data were conducted with ArcGIS Pro 2.5 and QantumGIS 3.10 software. The created image from the 2000s (when the tree-planting process in the study area was only just beginning) was compared with the contemporary image of 2020, thus providing quantitative data on progress in the tree-planting measures. Satellite data were carefully selected in terms of the time of acquisition: Landsat 7 data acquired on 28 April 2000 and Landsat 8 acquired on 27 April 2020 were used [30]. April is the period of transition of weather conditions from the dry season to the rainy season in the study area. During the dry season, low vegetation (mainly grassy) dies out almost completely and crops have already been harvested from fields, which exposes bare soil on the ground surface. Only the tree crowns (there are primarily evergreen trees) remain green, similarly to sparse shrubby vegetation in the immediate vicinity of watercourses, the lake shoreline, and scarce, irrigated field plots. Under such environmental conditions (April), the signal indicating vegetation recorded by the satellite may be interpreted with high probability as information on tree cover. The satellite acquisition in April provided records at minimal dust levels in the atmosphere, since the dry season in northern Nigeria is the time of the Harmattan, which peaks in the middle of the dry season (December-March). At the onset of the rainy season (in April), the Harmattan stops and the new vegetation has not yet emerged, which makes it possible to obtain an accurate representation of the land surface from satellite data.

Only the $30 \mathrm{~m}$-resolution Landsat data were used, which were inadequate for detailed differentiating among vegetation types, but the main objective was to obtain the differentiation between vegetation and nonvegetation within the land cover in the study area.

\section{Results}

\subsection{Tree Cover and Other Spatial Development Elements on the Land-Use Map}

As a result of field works and analysis of high-resolution Google Earth images from 2008, a land-use map was created for the Kubanni stream catchment area, focusing on the land owned by the university. This map, updated in 2020 (Figure 4), presents the following elements: 
- Housing districts of the university campus: area A, constructed before 1964, formerly belonging to St. Peter's College and the Nigerian College of Arts, Science and Technology, and housing areas BZ, F, E, G and G-Extension, ABU Qrts-3 and the Waterworks Quarters (constructed after 1966); most of them are densely wooded;

- $\quad \mathrm{ABU}$ teaching and administration areas, other facilities (Shika Hospital, Centre for Energy Research and Training), and some new developments (built after 2008);

- Areas marked as $\mathrm{Rv}$ are the parts of the land in which relics of original vegetation have been found, representing typical Guinea savanna, partly covering stabilized (inactive) areas degraded by gully erosion;

- Areas marked as Pl are plantations, which are described in Table 2; it was estimated that in the years from 2000 to 2008 approximately 20,000 trees were planted over a total area of approximately 159 ha, which gives the mean figure of 2500 trees per year. Figure 5 shows the examples of afforested areas of the ABU land. The total area planted with mahogany is 67.51 ha, mango 8.27 ha, cashew 8.99 ha and eucalyptus or eucalyptus together with neem 58.45 ha;

- Areas of new plantings (after 2008), marked as PLn, observed on the high-resolution Google Earth image in 2020, of which total area is approximately $0.6 \mathrm{~km}^{2}$ (60 ha) (Table 3). In the period from 2008 to 2020, the area planted with mahogany was 3.11 ha, mahogany together with other species (black plum, date palm, oil palm, white teak) 16.69 ha, black plum 4.4164 ha, mango 21.73 ha, white teak 8 ha, guava $1.663 \mathrm{ha}$, guava mixed with other species (cashew, mango and eucalyptus) $2.63 \mathrm{ha}$, eucalyptus 1.7485 ha;

- Areas marked as Gl are areas degraded by erosion (badlands, gully erosion). Their total area is $6.1619 \mathrm{~km}^{2}$ (616.19 ha), of which $3.3 \mathrm{~km}^{2}$ (330 ha) are within university grounds; this accounts for approximately $10.9 \%$ of the area owned by the university.

Table 2. A stand planted by ABU in the years 2000-2008, location and area.

\begin{tabular}{|c|c|c|c|c|}
\hline \multirow{2}{*}{$\begin{array}{l}\text { Denotation of Plantations } \\
\text { on the Land-Use Map in } \\
\text { Figure } 4\end{array}$} & \multirow{2}{*}{ Prevalent Tree Type } & \multicolumn{2}{|c|}{ Surface Area } & \multirow{2}{*}{$\begin{array}{l}\text { Coordinates of the } \\
\text { Central Point }\end{array}$} \\
\hline & & $\mathrm{km}^{2}$ & ha & \\
\hline Pl-1 & $\begin{array}{c}\text { mahogany } \\
\text { Khaya senegalensis }\end{array}$ & 0.2867 & 28.67 & $\begin{array}{c}11^{\circ} 09^{\prime} 25.24^{\prime \prime} \mathrm{N} \\
7^{\circ} 38^{\prime} 41.62^{\prime \prime} \mathrm{E}\end{array}$ \\
\hline $\mathrm{Pl}-2$ & $\begin{array}{c}\text { mahogany } \\
\text { Khaya senegalensis }\end{array}$ & 0.2365 & 23.65 & $\begin{array}{c}11^{\circ} 09^{\prime} 02.85^{\prime \prime} \mathrm{N}, \\
7^{\circ} 38^{\prime} 45.42^{\prime \prime} \mathrm{E}\end{array}$ \\
\hline Pl-3 & $\begin{array}{c}\text { mango } \\
\text { Mangifera indica }\end{array}$ & 0.08274 & 8.274 & $\begin{array}{c}11^{\circ} 08^{\prime} 36.07^{\prime \prime} \mathrm{N}, \\
7^{\circ} 38^{\prime} 59.76^{\prime \prime} \mathrm{E}\end{array}$ \\
\hline $\mathrm{Pl}-4$ & $\begin{array}{c}\text { cashew } \\
\text { Anacardium occidentale }\end{array}$ & 0.08997 & 8.997 & $\begin{array}{c}11^{\circ} 08^{\prime} 34.56^{\prime \prime} \mathrm{N}, \\
7^{\circ} 39^{\prime} 15.15^{\prime \prime} \mathrm{E}\end{array}$ \\
\hline Pl-5 & $\begin{array}{c}\text { mahogany } \\
\text { Khaya senegalensis }\end{array}$ & 0.1463 & 14.63 & $\begin{array}{c}11^{\circ} 08^{\prime} 49.49^{\prime \prime} \mathrm{N}, \\
7^{\circ} 39^{\prime} 36.98^{\prime \prime} \mathrm{E}\end{array}$ \\
\hline $\mathrm{Pl}-6$ & $\begin{array}{c}\text { mahogany } \\
\text { Khaya senegalensis }\end{array}$ & 0.005612 & 0.5612 & $\begin{array}{c}11^{\circ} 08^{\prime} 53.77^{\prime \prime} \mathrm{N}, \\
7^{\circ} 38^{\prime} 33.12^{\prime \prime} \mathrm{E}\end{array}$ \\
\hline $\mathrm{Pl}-7$ & $\begin{array}{c}\text { neem/eucalyptus/mahogany } \\
\text { Azadirachta indica/Eucalyptus } \\
\text { camaldulensis / Khaya } \\
\text { senegalensis }\end{array}$ & 0.5669 & 56.69 & $\begin{array}{c}11^{\circ} 07^{\prime} 47.10^{\prime \prime} \mathrm{N}, \\
7^{\circ} 38^{\prime} 59.21^{\prime \prime} \mathrm{E}\end{array}$ \\
\hline $\mathrm{Pl}-8$ & $\begin{array}{c}\text { eucalyptus } \\
\text { Eucalyptus camaldulensis }\end{array}$ & 0.01763 & 1.763 & $\begin{array}{c}11^{\circ} 08^{\prime} 25.11^{\prime \prime} \mathrm{N}, \\
7^{\circ} 39^{\prime} 08.24^{\prime \prime} \mathrm{E}\end{array}$ \\
\hline & Total & 1.4324 & 143.24 & - \\
\hline
\end{tabular}




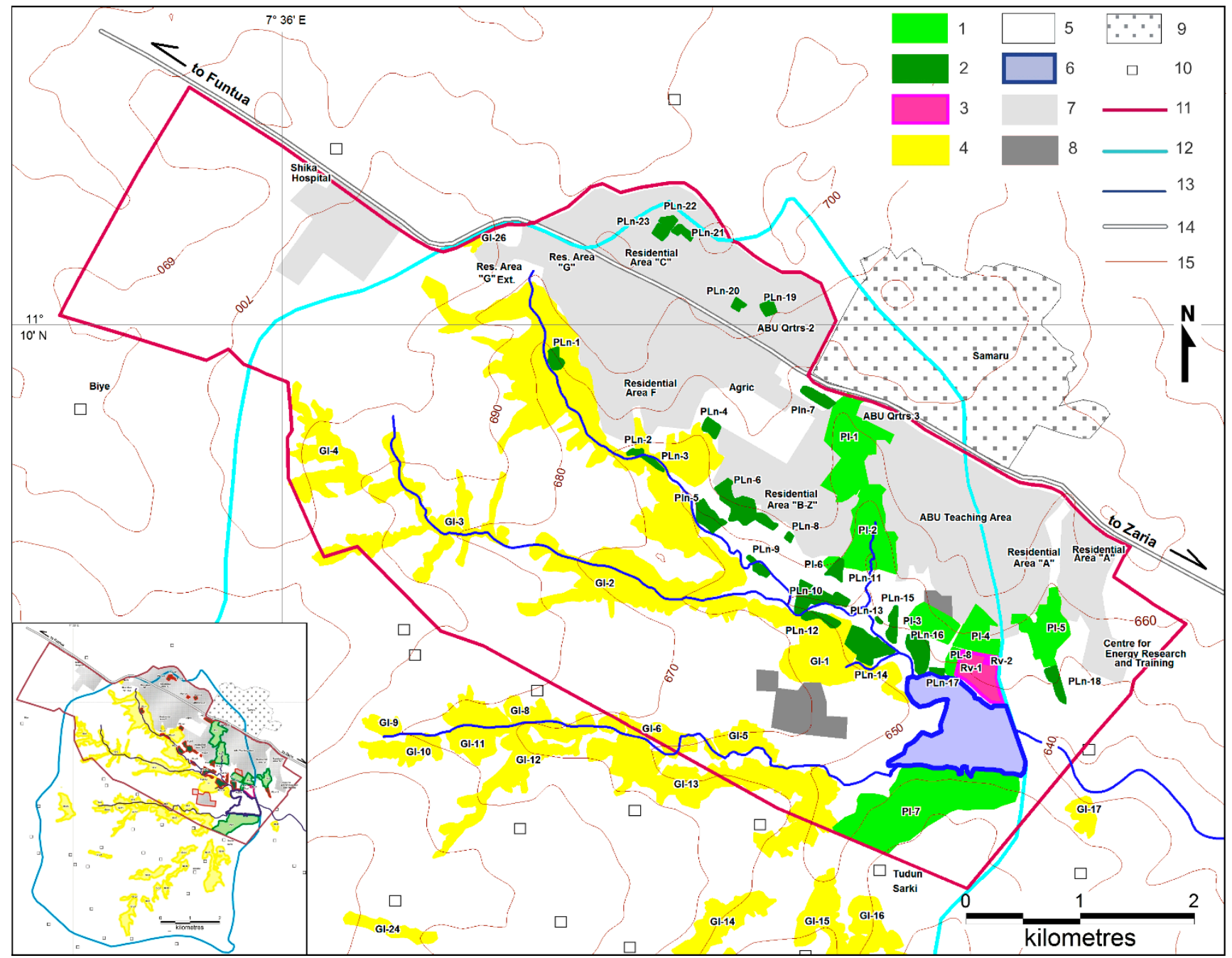

Figure 4. Part of the land-use map of the Kubanni stream catchment, focusing on the area belonging to ABU. The inset: a thumbnail image of the entire map showing the extent of Kubanni catchment area. Explanations: (1) plantations existing in 2008; (2) plantations established after 2008; (3) relics of natural vegetation; (4) bad lands, gully erosion; (5) farmland (mainly in the undeveloped part of the ABU land); (6) Kubanni lake; (7) developed area of the ABU campus, in some places densely wooded; (8) new developments (built after 2008); (9) big settlements outside of the university; (10) small villages; (11) boundary of the ABU land; (12) watershed; (13) stream; (14) road, (15) topographic contours [m a.s.l.].

Table 3. New plantings from the years 2008-2020, their location and area.

\begin{tabular}{|c|c|c|c|c|}
\hline \multirow{2}{*}{$\begin{array}{c}\text { Denotation of Plantations } \\
\text { on the Land-Use Map in } \\
\text { Figure } 4\end{array}$} & \multirow{2}{*}{ Prevalent Tree Type } & \multicolumn{2}{|c|}{ Surface Area } & \multirow{2}{*}{$\begin{array}{l}\text { Coordinates of the } \\
\text { Central Point }\end{array}$} \\
\hline & & $\mathrm{km}^{2}$ & ha & \\
\hline PLn-1 & $\begin{array}{l}\text { black plum (Malmo) } \\
\text { Vitex doniana }\end{array}$ & 0.01569 & 1.569 & $\begin{array}{l}11^{\circ} 9^{\prime} 50.14^{\prime \prime} \mathrm{N} \\
7^{\circ} 37^{\prime} 16.65^{\prime \prime} \mathrm{E}\end{array}$ \\
\hline PLn-2 & $\begin{array}{l}\text { black plum (Malmo) } \\
\text { Vitex doniana }\end{array}$ & 0.004799 & 0.4799 & $\begin{array}{l}11^{\circ} 9^{\prime} 24.22^{\prime \prime} \mathrm{N} \\
7^{\circ} 37^{\prime} 39.46^{\prime \prime} \mathrm{E}\end{array}$ \\
\hline PLn-3 & $\begin{array}{l}\text { black plum (Malmo) } \\
\text { Vitex doniana }\end{array}$ & 0.006265 & 0.6265 & $\begin{array}{l}11^{\circ} 9^{\prime} 20.98^{\prime \prime} \mathrm{N} \\
7^{\circ} 37^{\prime} 45.12^{\prime \prime} \mathrm{E}\end{array}$ \\
\hline PLn-4 & $\begin{array}{c}\text { mango } \\
\text { Mangifera indica }\end{array}$ & 0.1433 & 14.33 & $\begin{array}{c}11^{\circ} 9^{\prime} 31.28^{\prime \prime} \mathrm{N} \\
7^{\circ} 38^{\prime} 0.70^{\prime \prime} \mathrm{E}\end{array}$ \\
\hline
\end{tabular}


Table 3. Cont.

\begin{tabular}{|c|c|c|c|c|}
\hline \multirow{2}{*}{$\begin{array}{l}\text { Denotation of Plantations } \\
\text { on the Land-Use Map in } \\
\text { Figure } 4\end{array}$} & \multirow{2}{*}{ Prevalent Tree Type } & \multicolumn{2}{|c|}{ Surface Area } & \multirow{2}{*}{$\begin{array}{l}\text { Coordinates of the } \\
\text { Central Point }\end{array}$} \\
\hline & & $\mathrm{km}^{2}$ & ha & \\
\hline PLn-5 & $\begin{array}{l}\text { mahogany/black plum } \\
\text { (Malmo) } \\
\text { Khaya senegalensis/Vitex } \\
\text { doniana }\end{array}$ & 0.03407 & 3.407 & $\begin{array}{l}11^{\circ} 9^{\prime} 6.40^{\prime \prime} \mathrm{N} \\
7^{\circ} 37^{\prime} 59.34^{\prime \prime} \mathrm{E}\end{array}$ \\
\hline PLn-6 & $\begin{array}{c}\text { mango } \\
\text { Mangifera indica }\end{array}$ & 0.07087 & 7.087 & $\begin{array}{l}11^{\circ} 9^{\prime} 8.56^{\prime \prime} \mathrm{N} \\
7^{\circ} 38^{\prime} 9.45^{\prime \prime} \mathrm{E}\end{array}$ \\
\hline PLn-7 & $\begin{array}{c}\text { mahogany/date palm } \\
\text { Khaya senegalensis / Phoenix } \\
\text { dactylifera L. }\end{array}$ & 0.02154 & 2.154 & $\begin{array}{l}11^{\circ} 9^{\prime} 39.49^{\prime \prime} \mathrm{N} \\
7^{\circ} 38^{\prime} 30.62^{\prime \prime} \mathrm{E}\end{array}$ \\
\hline PLn-8 & $\begin{array}{c}\text { mango } \\
\text { Mangifera indica }\end{array}$ & 0.003108 & 0.3108 & $\begin{array}{l}11^{\circ} 9^{\prime} 0.50^{\prime \prime} \mathrm{N} \\
7^{\circ} 38^{\prime} 22.59^{\prime \prime} \mathrm{E}\end{array}$ \\
\hline PLn-9 & $\begin{array}{c}\text { white teak } \\
\text { Gmelina arborea }\end{array}$ & 0.01113 & 1.113 & $\begin{array}{l}11^{\circ} 8^{\prime} 51.93^{\prime \prime} \mathrm{N} \\
7^{\circ} 38^{\prime} 13.92^{\prime \prime} \mathrm{E}\end{array}$ \\
\hline PLn-10 & $\begin{array}{c}\text { mahogany/white teak } \\
\text { Khaya senegalensis/ Gmelina } \\
\text { arborea }\end{array}$ & 0.05603 & 5.603 & $\begin{array}{l}11^{\circ} 8^{\prime} 43.49^{\prime \prime} \mathrm{N} \\
7^{\circ} 38^{\prime} 31.82^{\prime \prime} \mathrm{E}\end{array}$ \\
\hline PLn-11 & $\begin{array}{c}\text { mahogany/white teak } \\
\text { Khaya senegalensis/Gmelina } \\
\text { arborea }\end{array}$ & 0.01402 & 1.402 & $\begin{array}{l}11^{\circ} 8^{\prime} 51.19^{\prime \prime} \mathrm{N} \\
7^{\circ} 38^{\prime} 35.18^{\prime \prime} \mathrm{E}\end{array}$ \\
\hline PLn-12 & $\begin{array}{c}\text { guava } \\
\text { Psidium guajava }\end{array}$ & 0.01663 & 1.663 & $\begin{array}{l}11^{\circ} 8^{\prime} 37.29^{\prime \prime} \mathrm{N} \\
7^{\circ} 38^{\prime} 27.33^{\prime \prime} \mathrm{E}\end{array}$ \\
\hline PLn-13 & $\begin{array}{c}\text { white teak } \\
\text { Gmelina arborea }\end{array}$ & 0.001249 & 0.1249 & $\begin{array}{l}11^{\circ} 8^{\prime} 37.12^{\prime \prime} \mathrm{N} \\
7^{\circ} 38^{\prime} 47.79^{\prime \prime} \mathrm{E} \\
\end{array}$ \\
\hline PLn-14 & $\begin{array}{l}\text { black plum (Malmo) } \\
\text { Vitex doniana }\end{array}$ & 0.01741 & 1.741 & $\begin{array}{l}11^{\circ} 8^{\prime} 33.02^{\prime \prime} \mathrm{N} \\
7^{\circ} 38^{\prime} 51.36^{\prime \prime} \mathrm{E}\end{array}$ \\
\hline PLn-15 & $\begin{array}{c}\text { white teak } \\
\text { Gmelina arborea }\end{array}$ & 0.06764 & 6.764 & $\begin{array}{l}11^{\circ} 8^{\prime} 29.99^{\prime \prime} \mathrm{N} \\
7^{\circ} 38^{\prime} 45.28^{\prime \prime} \mathrm{E}\end{array}$ \\
\hline PLn-16 & $\begin{array}{c}\text { mahogany/oil palm } \\
\text { Khaya senegalensis/Elaeis } \\
\text { guineensis }\end{array}$ & 0.04119 & 4.119 & $\begin{array}{l}11^{\circ} 8^{\prime} 27.42^{\prime \prime} \mathrm{N} \\
7^{\circ} 38^{\prime} 59.06^{\prime \prime} \mathrm{E}\end{array}$ \\
\hline PLn-17 & $\begin{array}{c}\text { guava/cashew } \\
\text { Psidium guajava/Anacardium } \\
\text { occidentale }\end{array}$ & 0.004791 & 0.4791 & $\begin{array}{c}11^{\circ} 8^{\prime} 22.69^{\prime \prime} \mathrm{N} \\
7^{\circ} 39^{\prime} 4.04^{\prime \prime} \mathrm{E}\end{array}$ \\
\hline PLn-18 & $\begin{array}{l}\text { guava/mango/eucalyptus } \\
\text { Psidium guajava/Mangifera } \\
\text { indica and }\end{array}$ & 0.02151 & 2.151 & $\begin{array}{l}11^{\circ} 8^{\prime} 19.11^{\prime \prime} \mathrm{N} \\
7^{\circ} 39^{\prime} 37.35^{\prime \prime} \mathrm{E}\end{array}$ \\
\hline PLn-19 & $\begin{array}{c}\text { eucalyptus } \\
\text { Eucalyptus camaldulensis }\end{array}$ & 0.01117 & 1.117 & $\begin{array}{l}11^{\circ} 10^{\prime} 4.80^{\prime \prime} \mathrm{N} \\
7^{\circ} 38^{\prime} 16.62^{\prime \prime} \mathrm{E}\end{array}$ \\
\hline PLn-20 & $\begin{array}{c}\text { eucalyptus } \\
\text { Eucalyptus camaldulensis }\end{array}$ & 0.006315 & 0.6315 & $\begin{array}{c}11^{\circ} 10^{\prime} 5.70^{\prime \prime} \mathrm{N} \\
7^{\circ} 38^{\prime} 8.37^{\prime \prime} \mathrm{E}\end{array}$ \\
\hline PLn-21 & $\begin{array}{c}\text { mahogany } \\
\text { Khaya senegalensis }\end{array}$ & 0.01021 & 1.021 & $\begin{array}{c}11^{\circ} 10^{\prime} 25.79^{\prime \prime} \mathrm{N} \\
7^{\circ} 37^{\prime} 52.64^{\prime \prime} \mathrm{E}\end{array}$ \\
\hline PLn-22 & $\begin{array}{c}\text { mahogany } \\
\text { Khaya senegalensis }\end{array}$ & 0.009595 & 0.9595 & $\begin{array}{c}11^{\circ} 10^{\prime} 28.54^{\prime \prime} \mathrm{N} \\
7^{\circ} 37^{\prime} 48.45^{\prime \prime} \mathrm{E}\end{array}$ \\
\hline PLn-23 & $\begin{array}{c}\text { mahogany } \\
\text { Khaya senegalensis }\end{array}$ & 0.01133 & 1.133 & $\begin{array}{c}11^{\circ} 10^{\prime} 26.00^{\prime \prime} \mathrm{N} \\
7^{\circ} 37^{\prime} 46.46^{\prime \prime} \mathrm{E}\end{array}$ \\
\hline Total & & 0.599862 & 59.99 & \\
\hline
\end{tabular}




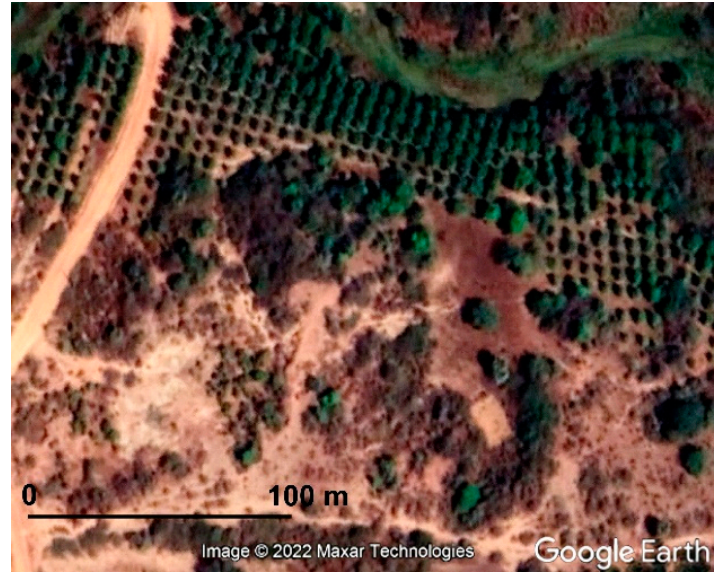

(a)

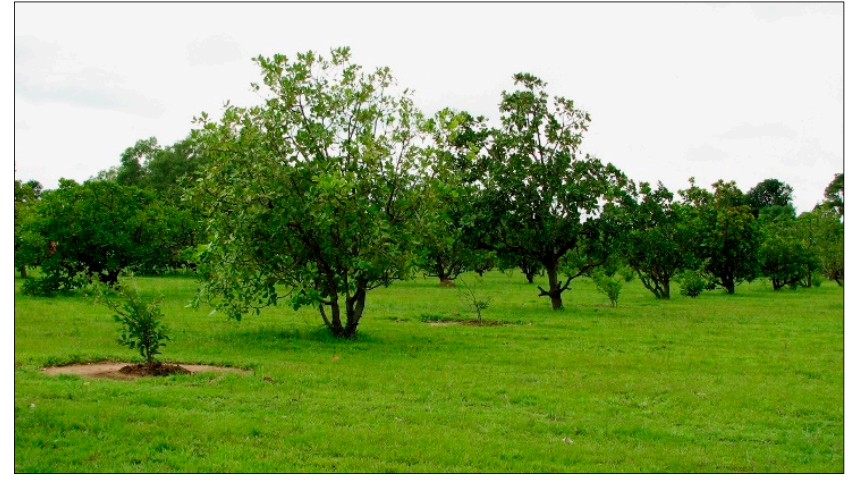

(b)

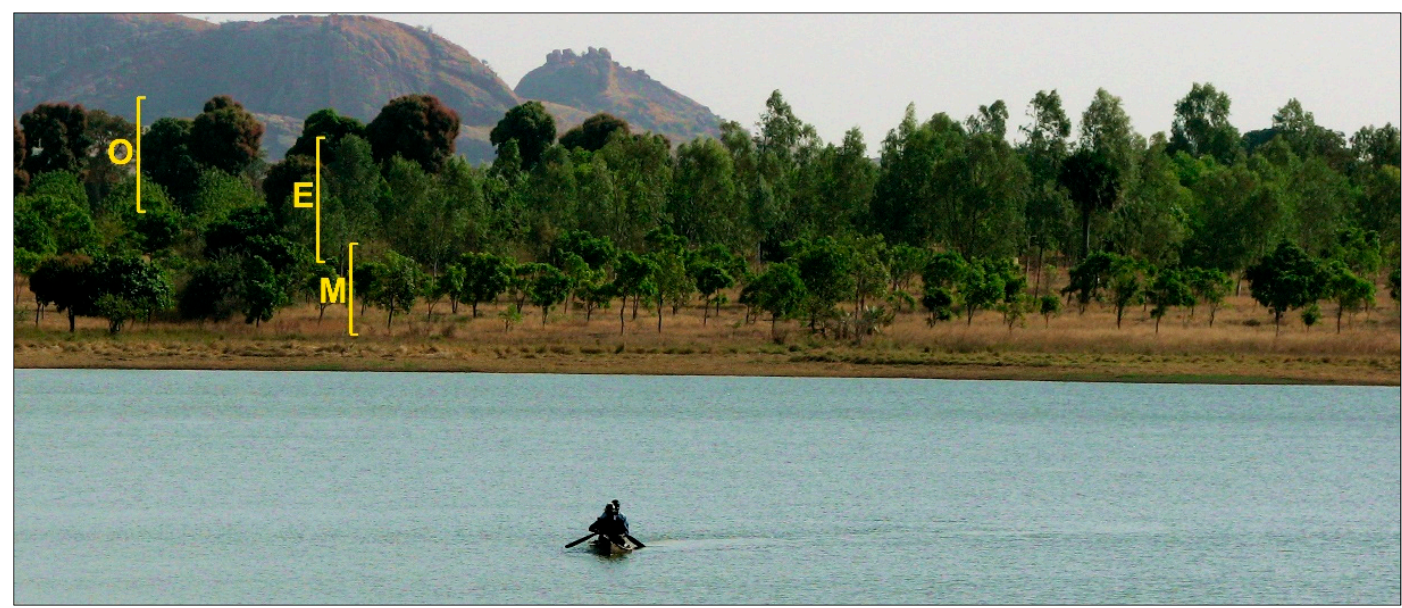

(c)

Figure 5. Plantations in the Ahmadu Bello University grounds: (a) high-resolution image available in Google Earth (Image (C 2022 Maxar Technologies) [29] presenting new plantings (Pln-14 in Figure 4) on the edge of the land affected by erosion; (b) a photograph of the section planted with cashew trees aged several years; (c) a view of the Kubanni reservoir shore overgrown with layers of vegetation (Pl-7 in Figure 4): in the foreground are the youngest mahogany trees (M), behind-the older eucalyptus trees (E), in the background is the oldest tree generation (O) (Photos by E.E. Kurowska 2008).

Analysing the plantings both from 2000 to 2008 and those later, it can be seen that the main form of the arrangement of planted trees is regular spacing of 6 to $10 \mathrm{~m}$ in rows. Most of the planted areas consist of a single-species stand, though these later plantations become more varied, and some of them consist of two or three species (Tables 2 and 3).

\subsection{Tree Cover Estimated from Landsat Images}

The Landsat imageries were evaluated on the basis of its spectral band combinations to clearly distinguish major land-cover components with particular emphasis on vegetation. This was done successfully, and the effect shows the serious expansion of green area when comparing the 2000 and 2020 imageries (Figure 6).

Comparing the extent of vegetation cover in the Landsat images (Figure 6) to the landuse map (Figure 4), it is noted that the effect of increased territorial green cover is largely due to the establishment of plantations in the area south of the campus. However, there is also an effect of dense tree cover in the residential areas of the campus (residential areas $\mathrm{A}$, C, G, B-Z and particularly area F), which was already observed in 2000, but significantly strengthened in 2020. 


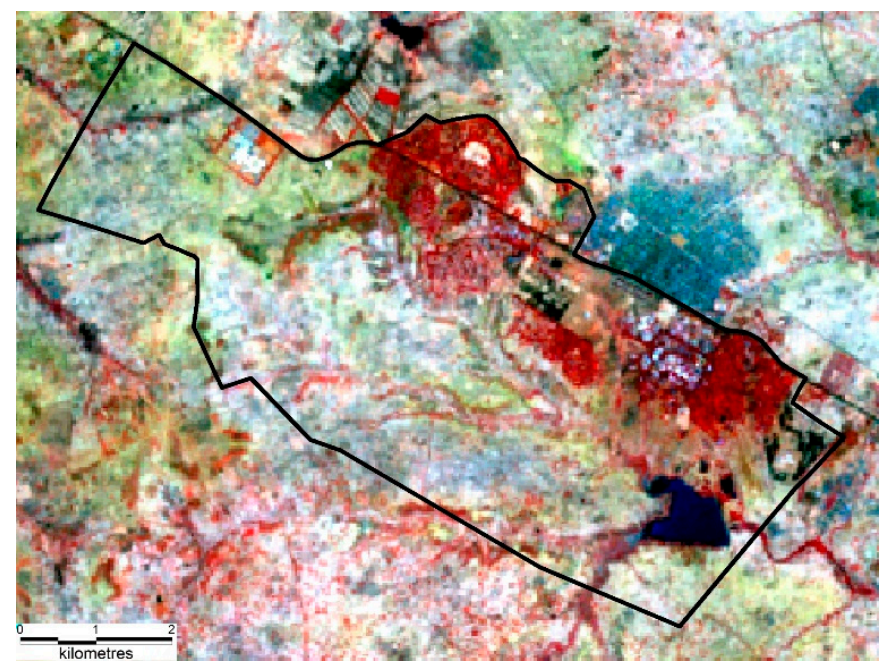

(a)

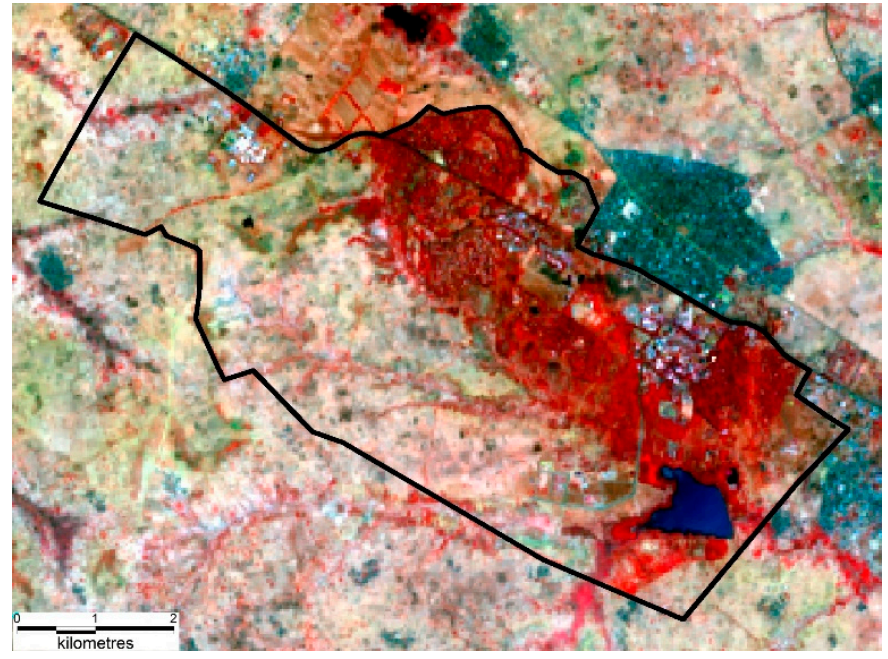

(b)

Figure 6. A comparison of the spatial distribution of vegetation cover in Landsat 7 image from 2000 (bands 432, image (a)) and Landsat 8 from 2020 (bands 543, image (b)) [30], in both cases, data were collected at the end of April (04.27 and 04.28, respectively. Such band combinations display vegetation as red colour. Due to the season when satellite data were collected, greenery is largely represented by trees (Landsat 7 data acquired on 28 April 2000 and Landsat 8 acquired on 27 April 2020). The boundary of the study area (land owned by ABU) is indicated by a black line (comparison with the land-use map in Figure 4). A significant increase in wooded land over the time period from 2000 to 2020 is evident.

The next step in processing the Landsat data was to calculate the NDVI and other vegetation indices so that vegetation could be distinguished from among the other landcover types. The NDVI for the 2000 satellite data took values from -0.4119 to 0.3781 ; the mean NDVI value was 0.2713 with a standard deviation of 0.0854 . For the 2020 satellite data, the NDVI took values from -0.5389 to 0.8802 ; the mean NDVI value was 0.1635 with a standard deviation of 0.1186 . NDVI values from 0.27 upwards were taken to classify the vegetation in the resulting raster image. As a final result, the area covered by vegetation was estimated and the following values were obtained: $6.88 \mathrm{~km}^{2}$ (688.17 ha) in 2000 and $12.24 \mathrm{~km}^{2}$ (1224.35 ha) in 2020 (Figure 7). This means that while in 2000 the area of the ABU land was covered by vegetation, mainly woody vegetation in $22.8 \%$, in 2020 it was already $40.5 \%$ of the ABU area and the green cover almost doubled. 


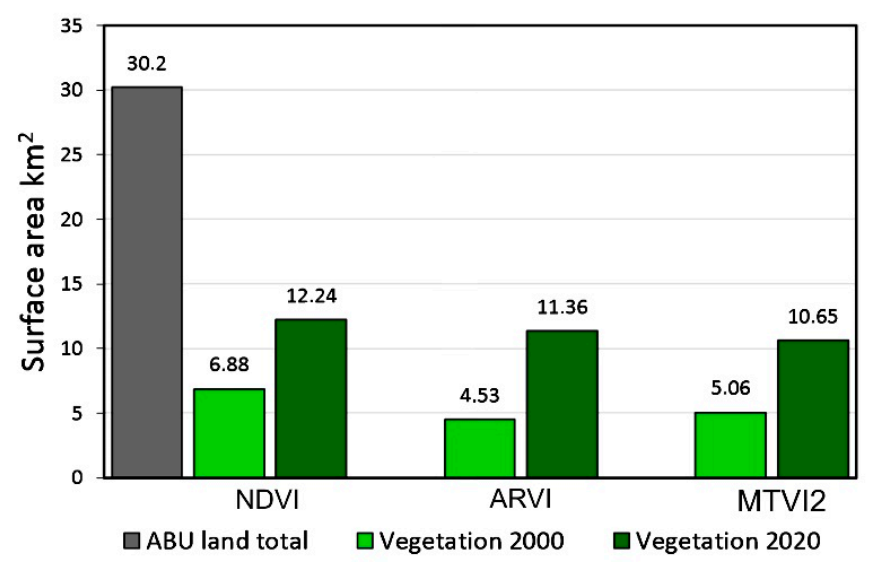

Figure 7. Vegetation cover development in the ABU land. Results of the surface area estimation of vegetation cover in April 2000 and April 2020 based on NDVI, ARVI and MTVI2 indices derived from Landsat 7 and Landsat 8 data.

The other indices chosen for the analysis showed a slightly lower area covered with vegetation (Figure 7). ARVI 2000 and 2020 gave a range of values from -0.5202 to 0.5196 and -0.5992 to 0.5508 , respectively, and the vegetated area was classified with values above 0.0 ; for the MTVI2 2000 and 2020 the ranges of values from -0.2643 to 0.4326 and from -0.2665 to 0.3570 were obtained, and the vegetation cover was marked with values above 0.016 . Thus, the ARVI calculations resulted in area covered with vegetation, mainly afforested, of $4.53 \mathrm{~km}^{2}$ in 2000 and $11.36 \mathrm{~km}^{2}$ by 2020 , and MTVI2 $5.6 \mathrm{~km}^{2}$ and $10.65 \mathrm{~km}^{2}$, respectively. The differences arose, among others, from the fact that NDVI represented vegetation with a greater share of low vegetation cover, especially in wet regions: in the valleys of watercourses, irrigated areas and specially the shores of the lake, whereas ARVI and MTVI2 were more sensitive to background and are probably better at separating soil and grassy vegetation from wooded areas. Moreover, some difficulties in classification resulted from the fact that some built-up areas of the ABU were also densely wooded. Generally, considering all the three vegetation indices, it can be concluded that the vegetation cover, mainly wooded vegetation, more or less doubled in the period from 2000 to 2020 .

\section{Discussion}

\subsection{Common African Environmental Problems also Present in the ABU Area}

The presented case of Ahmadu Bello University represents on a microscale the chain of environmental problems and interdependencies between nature and humans, characteristic to extensive areas of Africa. Thus, an increase in the population size and a continuously growing demand for new land for agricultural use is observed [39-41], along with intensive and continuous cultivation, soil degradation, erosion [42-45], subsequent deforestation [46-49] and a constant threat of serious water shortages [50-52]. The need to protect forests and restore stands, particularly those of native tree species, as well as plant new trees around the rapidly growing agglomerations and in agricultural areas has been advocated by scientists and experts in numerous publications, and these measures have been implemented in some areas in Africa, including some parts of northern Nigeria [53-55]. In many regions of the world, including Africa, the impact of civilization is so strong that spontaneous recovery of tree cover and forest is impossible without purposeful corrective actions. Africa needs so-called tall vegetation, but it should be rationally introduced in locations from which it has been removed, or seemingly definitely and irrevocably eliminated. The ABU actions in this respect provide evidence that consistent, long-term efforts focused on environmental management, as well as the environmental awareness of the local communities, may bring positive results, manifested in the increment in green and tree-covered areas. 


\subsection{Tree Cover Extent and Land Cover State Derived from Satellite Data}

The increment of the tree-cover was indicated by the NDVI method used for the Landsats 2000 and 2020 analysis. The method is readily applied in studies of the variability and condition of vegetation cover in Africa, including Nigeria [17,34,35]; it generally provides information on the occurrence and density of vegetation [33]. However, in this study, from the range of options, only the possibility of examining the presence of vegetation and the area it occupied was used, because the analysed area was not very extensive.

The effect of vegetation cover development derived from the presented Landsat images corresponds with the result obtained from the interpretation of the Google Earth image digitized and shown on the land-use map, although they differ in scale and precision of imaging due to the different resolution of the input data. In the case of Landsats, the main effect is the observed difference in the areas covered with vegetation, comparing the years 2000 and 2020. The land-use map presents the distribution of the plots of land planted over 20 years. Comparing the Landsat images and the Google Earth land-use map it can be observed that the vegetation cover includes plantations and a part of the developed campus with dense old stand as well (mainly residential districts).

The distribution of planted plots derived from the Google Earth images shows that during the earlier phase of the afforestation project they were mostly located close to the main campus, or even integrated into the urbanized districts, and their surface areas were more extensive (from 0.56 to $56.7 \mathrm{ha}$ ) comparing to the plantations established later. The later ones, which were usually smaller (from 0.125 to $14.3 \mathrm{ha}$ ), are in most cases located south of the built-up area, closer to the land affected by gully erosion. Hence, there was an observation that in the initial phase of planting, the priority was probably to stabilize and protect the land surface by introducing the vegetation cover in the threatened parts of the main campus. The exception was the P17 region stabilizing the southern coast of the Kubanni reservoir. Later in the afforestation project, the plantations were located mostly in a belt parallel to one of the main stream valleys, clearly affected by gully erosion. Thus, the focus was already directed on protecting the land surface in that part, which is the main source of material transported to the reservoir, causing its siltation. Hence, the effect of the plantings so far seems to be a green barrier covering the southern edge of the developed part of the university area, gradually expanding towards problematic zones degraded by erosion.

This experience shows that some basic tools and data such as high-resolution Google Earth images may be of practical importance. Their usefulness was demonstrated not only in the described Zaria case study, but also in other works. Google Earth is used by researchers in various disciplines to facilitate their work both in basic and applied sciences. This shows huge potential for enriching the geographical background in studies on land relief forms and extensive analyses of various environments: river systems, lakes, wetlands, coastal elements, landslides, as well as forms of glacial and desert areas [56,57]. Other examples include mapping of soil erosion effects, e.g., badlands in Karoo, RSA, investigated by Boardman et al. in 2015 [6]. Finally, high-resolution images of the Earth provided by Google Earth are useful sources for the analyses of land use or preparation of land-use maps for regions of interest, which may be helpful for management purposes or by planners $[58,59]$. This potential was also used in the presented work. The advantages of this source of spatial information include:

- It is open source;

- It provides the latest satellite imagery;

- It has high spatial resolution;

- Popular software have provided tools for easy and efficient acquisition and use of Google Earth images;

- It provides images acquired at different times, which helps to detect land-use changes [56];

- Possibility of fast browsing coupled with digitization tools helps to directly export processing results to the local GIS [58]. 


\subsection{Single-Species and Mixed Planting Systems}

To date, the most frequent form of tree planting in the $\mathrm{ABU}$ grounds has been to cover relatively small areas with a single-species stand, forming even rows by planting saplings at uniform spacings ranging from several to $10 \mathrm{~m}$ (Figure $5 \mathrm{a}, \mathrm{b}$ ). The number of planted useful and fast-growing species dominate over the native species (Table 2). In this way, such areas are referred to as small plantations. Afforestation in the form of plantations, as seen in the ABU premises, shows many positive aspects; however, monocultures are susceptible to biotic and abiotic threats [60]. Such an afforestation model applied several decades ago in other regions of the world (e.g., central Europe) failed to succeed, since stands were not ecologically viable and at present require huge resources and effort of foresters to be rebuilt by the introduction of admixture species.

At ABU, among the earlier plantings (2000-2008), out of all eight small plantations, seven were single-species plantings, and only one was mixed, although this was the largest. However, in the latter part of the project (2008-2020), some progress was noticed towards the introduction of mixed stands, as 7 out of 23 planted plots were two- and three-species stands. There was also an increase in the number of species planted.

Continuing the process of planting-system upgrading, the preference for biogroups in the form of multispecies and multistorey tree plantings, structurally resembling natural plant cover, is proposed, which may in the future bring even better results for the environment and ecosystems developing in the study area. Many studies have shown that mixed forests are more resistant to natural disturbances and threats [61-65]. Therefore, it is worth considering the use of methods of planting, tending and protecting trees that are different from plantation type. This different method involves the creation of species-diversified biogroups. A biogroup is considered to be a form of community life, making it easier for trees to effectively counter the competition of other species. In biogroups, the distances between trees are markedly smaller than those between neighbouring trees. Advantages of growing within a biogroup may also include the fusion of root systems in trees of the same species, leading to the forming a kind of a single organism, supported by the joint root system and the assimilative apparatus, resulting in more efficient utilization of moisture and minerals found in the soil [66-68]. Biocenotic admixtures, i.e., tree and shrub species introduced to stands, promote and enhance advantageous biocenotic conditions and contribute to the health and natural resistance of the forest, while additionally sustaining wildlife populations. The establishment of biogroups is relatively cheaper than afforestation of large areas. The rationale for the establishment of biogroups is that in enclaves of properly selected species, the trees and shrubs are spatially supplementary and serve as shelter planting. Such a biogroup, with adequate preliminary tending operations and protection, may initiate desirable natural spatial succession.

The proposed biogroups should be composed of tree species valuable for a given area, sheltered by trees and shrubs serving this function in the horizontal and vertical system. Biogroups may be established as mosaics both over open spaces and as additional plots in plantations. Such biogroups may be protected using various methods:

- Mechanical (shielding individual specimens with tube, mesh and spiral trunk protectors, fencing and shelter belts of fast-growing species);

- Biological (application of certain living organisms to reduce the populations of others, e.g., insect pests and pathogenic fungi);

- Chemical (animal repellents, fungicides, insecticides, etc.);

- Integrated measures.

\subsection{Extending the Planting Initiative in the Rural ABU Neighborhood}

Ahmadu Bello University as an educational institution promotes the concept of tree planting both among students and the general public in Zaria and the Kaduna State; it is even known on the national scale for the regularly organized tree-planting campaigns. Students are involved in these promotional and research activities. Such studies conducted among farmers living in the nearby villages are a source of valuable information, 
e.g., on the participation of the local farming communities in the afforestation efforts, their successes and problems. It has been found that the species particularly preferred by farmers include neem, citrus, acacia (Acacia Senegal), guava, mango, baobab (Adansonia digitata), cashew, tamarind (Tamarindus indica), shea tree (Vitellaria paradoxa) and mahogany (being the least popular here). Farmers plant trees most willingly in the immediate vicinity of their houses, and only rarely in agricultural land. They are typically most interested in obtaining seedlings of such species as mango, guava, cashew and citrus trees, since they believe they bring fast and relatively high profits. This approach is quite common in West Africa and other parts of the world as well. As shown by experiences from Nigeria [69], Benin [70], Ghana [43], Burkina Faso [71] and other regions of the Sahel, the most popular tree species in agroforestry systems are utility species contributing to food and medicine enrichment, and those that provide the possibility of commercial use. Especially for small farmers, it is important to be able to obtain additional income from the trees planted on their farms. The other utility functions of trees valued by local farmers are shading and windbreaking, contribution to soil fertility, and finally, provision of fodder for livestock [69]. Unfortunately, farmers often face difficulties with tree planting, indicating causes such as extreme drought in the dry season, particularly in the first year. Some farmers also complain that trees compete for light with crop plants. Water and applied plant nutrients also attract birds and insects as well as pests, hindering appropriate plant growth. Occasionally, when seedlings grow too close to irrigation ditches providing fields with water, they also disrupt water flow [72]. The local populations also indicate certain factors as obstacles hindering such measures and discouraging them from undertaking tree-planting actions: a lack of tree seedlings, problems with irrigation, difficulties with financing, lack of creditworthiness, insufficient access to information, invasions of pests and diseases, as well as serious damage to seedlings by farm animals, particularly at early stages of plant growth. It is not surprising that the report on the Kubanni environment [25] showed the need to allocate funds for the necessary protection of tree-planted areas in the cost estimates for the proposed biological environment revitalization solutions in the ABU land. Both researchers and villagers agree when saying that multifaceted protection of new plantings is required, including security personnel protecting them against cattle grazing, e.g., migrating hers, protection against farm animals or simply against vandals. Many of the above-mentioned issues may again refer to the current problems faced on the national scale, as well as most of the African continent outside Nigeria. These problems include continuous clashes for water and land resources, conflicts between cattle breeders and farmers leading to social unrest, invariably fuelled by the increasing population, and compounded by political, ethnic and religious differences [73-76]. In view of these serious social problems and clashes for agricultural land required to produce food for the growing population, it is often difficult to provide convincing arguments to support land revitalization by afforestation. In this case, an argument may be provided by the potential benefits and profits for farmers, generated within a short period of time by planted stands; however, this generates the introduction of useful species rather than a return to sets of native species. So, agroforestry systems may be an attractive method of cultivation, linked at the same time to the idea of planting biogroups, dissemination of biodiversity and promoting afforestation advantages outside of the ABU.

The university mission in general is to serve the public good, spread knowledge based on the latest advances in science and to educate the inhabitants to creatively apply this knowledge in practice. Thus, Ahmadu Bello University may play an important role in the dissemination of knowledge in forestry and life sciences among the general public. This is essential since-as shown by the survey results mentioned above-the local communities frequently lack such knowledge and needed skills. 


\section{Conclusions}

The experience gained based on the example from Ahmadu Bello University in Zaria in the years 2000-2020, as presented in this paper, may provide inspiration and guidance for the regeneration of parts of woodland in the savanna zone of Nigeria. Regardless of the tree-planting method, the success of ABU's afforestation actions may be commended here, as documented by the increase in the permanently green cover from $22.8 \%$ of the total ABU land in 2000 to $40.5 \%$ in 2020, of which the wooded vegetation cover can be estimated at approximately $16.8 \%$ in 2000 and $35.5 \%$ in 2020 - as shown by analysis of Landsat 7 and Landsat 8 images. Taking into account the establishing of plantations from 2000 to present, the increase in the afforested area during these 20 years amounted to 219.9 ha $\left(2.199 \mathrm{~km}^{2}\right)$, yet the dynamics of tree planting were higher in the 2000-2008 period than later, as shown by the analysis of high-resolution images from Google Earth. The main form of distribution for the introduced tall vegetation is regular spacing with considerable inter-row distances amounting to approximately $10 \mathrm{~m}$. Most of the inventoried plots were planted with a single-species stand, so the afforestation took the form of monoculture. In small projects, such as the ABU activity, it seems advantageous to introduce multispecies enclaves, even in the form of small biogroups with irregular areas embedded into the typical plantation spacing system. Local communities can be involved in such a new planting system if they are aware of the benefits of planting trees and are supported in the process.

As a result of these studies, a land-use map was constructed with high detail and accuracy that was not previously available to the land administrators. The importance of GIS tools in the mapping process is not to be underestimated. This technique led to precisely defining the percentage of erosion degradation (approximately $10.9 \%$, i.e., 330 ha or $3.3 \mathrm{~km}^{2}$ of the ABU land) and an inventory of wooded area was made, which provides valuable information for making further decisions on future environmental measures in ABU. In African circumstances (soil degradation, desertification, large-scale man-made changes to vegetation), free and accessible remote sensing and GIS data and tools may be of great and practical importance for effective and sustainable land management. Easily accessible products such as Google Earth, presenting details of land cover, can be used even by local governments, if assisted by professionals, and may support authorities of some African communities whose interest is to protect the environment and its resources in the places where they live.

Author Contributions: Conceptualization, E.E.K. and A.C.; methodology, E.E.K.; validation, A.C.; investigation, E.E.K. and M.L.G.; resources, A.C., E.E.K. and M.L.G.; data curation, E.E.K.; writingoriginal draft preparation, A.C., E.E.K. and M.L.G.; writing-review and editing, A.C., E.E.K. and M.L.G.; visualization, E.E.K.; supervision, E.E.K.; project administration, E.E.K.; funding acquisition, A.C. All authors have read and agreed to the published version of the manuscript.

Funding: The publication is co-financed within the framework of Ministry of Science and Higher Education programme as "Regional Initiative Excellence" in years 2019-2022, project number 005/RID/2018/19.

Institutional Review Board Statement: Not applicable.

Informed Consent Statement: Not applicable.

Data Availability Statement: Not applicable.

Acknowledgments: We express our gratitude to the late Krzysztof Schoeneich for his invaluable assistance in carrying out this work. We also thank Małgorzata Manowska and Rafał Borkowski for their technical assistance.

Conflicts of Interest: The authors declare no conflict of interest. 


\section{References}

1. Global Forest Resources Assessment 2015. How Are the World's Forests Changing? 2nd ed.; Food and Agriculture Organization of the United Nations: Rome, Italy, 2016. Available online: http:/ / www.fao.org/3/i4793e/i4793e.pdf (accessed on 13 January 2021).

2. Adesina, J.B. Global Forest Resources Assessment. Country Report Nigeria; Forestry Department, Food and Agriculture Organization of the United Nations: Rome, Italy, 2005. Available online: http:/ / www.fao.org/forestry /8968-08a7263cd02b0795f7ead548824725 c86.pdf (accessed on 28 January 2021).

3. Amosun, O.O.; Adedoyin, O.S. Global Forest Resources Assessment 2010. Country Report Nigeria; Forestry Department, Food and Agriculture Organization of the United Nations: Rome, Italy, 2010. Available online: http://www.fao.org/3/al586E/al586E.pdf (accessed on 28 January 2021).

4. Adedoyin, O.S.; Aluko, S.O.; Olabode, M.A.; Ajibola, A.A.; AJagun, E.O.; Ajakaye, O.C. Global Forest Resources Assessment 2015. Country Report Nigeria; Forestry Department, Food and Agriculture Organization of the United Nations: Rome, Italy, 2014. Available online: http:/ / www.fao.org/3/az293e/az293e.pdf (accessed on 28 January 2021).

5. Borrelli, P.; Robinson, D.A.; Fleischer, L.R.; Lugato, E.; Ballabio, C.; Alewell, C.; Panagos, P. An assessment of the global impact of 21st century land use change on soil erosion. Nat. Commun. 2017, 8, 1-13. [CrossRef]

6. Boardman, J.; Foster, I.L.; Favis-Mortlock, D. A 13-year record of erosion on badland sites in the Karoo, South Africa. Earth Surf. Process. Landf. 2015, 40, 1964-1981. [CrossRef]

7. Kiage, L.M. Perspectives on the assumed causes of land degradation in the rangelands of Sub-Saharan Africa. Prog. Phys. Geogr. 2013, 37, 664-684. [CrossRef]

8. Third National Communication (TNC) of the Federal Republic of Nigeria, under the United Nations Framezork Convention on Climate Change (UNFCCC); Federal Ministry of Environment: Abuja, Nigeria, 2020. Available online: https: / /www4.unfccc.int/ sites/ SubmissionsStaging/NationalReports/Documents /187563_Nigeria-NC3-1-TNC\%20NIGERIA\%20-\%2018-04-2020\%20-\%2 OFINAL.pdf (accessed on 15 January 2021).

9. Derrick, J. The Great West African Drought, 1972-1974. Afr. Aff. 1977, 76, 537-586. [CrossRef]

10. Oladipo, E.O. A comprehensive approach to drought and desertification in northern Nigeria. Nat. Hazards 1993, 8, $235-261$. [CrossRef]

11. Gonzalez, P.; Tucker, C.J.; Sy, H. Tree density and species decline in the African Sahel attributable to climate. J. Arid Environ. 2012, 78, 55-64. [CrossRef]

12. Mouhamed, L.; Traore, S.B.; Alhassane, A.; Sarr, B. Evolution of some observed climate extremes in the West African Sahel. Weather. Clim. Extrem. 2013, 1, 19-25. [CrossRef]

13. Olaniyi, O.A.; Ojekunle, Z.O.; Amujo, B.T. Review of climate change and its effect on Nigeria ecosystem. Int. J. Afr. Asian Stud. Open Access Int. J. 2013, 1, 57-65.

14. Eniolorunda, N.B.; Mashi, S.A.; Nsofor, G.N. Toward achieving a sustainable management, characterization of land use/land cover in Sokoto Rima floodplain, Nigeria. Environ. Dev. Sustain. 2016, 19, 1855-1878. [CrossRef]

15. Sedano, F.; Molini, V.; Azad, M. A mapping framework to characterize land use in the Sudan-Sahel region from dense stacks of Landsat data. Remote Sens. 2019, 11, 648. [CrossRef]

16. Falaki, M.A.; Ahmed, H.T.; Akpu, B. Predictive modeling of desertification in Jibia Local Government area of Katsina State, Nigeria. Egypt. J. Remote Sens. Space Sci. 2020, 23, 363-370. [CrossRef]

17. Badamasi, M.M.; Yelwa, S.A.; Abdul Rahim, M.A.; Noma, S.S. NDVI threshold classification and change detection of vegetation cover at the Falgore Game Reserve in Kano State, Nigeria. Sokoto J. Soc. Sci. 2010, 2, 174-194. Available online: https:/ / www.academia.edu/4365548/NDVI_threshold_classification_and_change_detection_of_vegetation_cover_at_ Falgore_Game_Reserve_in_Kano_State_Nigeria (accessed on 25 January 2021).

18. Suleiman, M.S.; Wasonga, O.V.; Mbau, J.S.; Elhadi, Y.A. Spatial and temporal analysis of forest cover change in Falgore Game Reserve in Kano, Nigeria. Ecol. Process. 2017, 6, 1-13. [CrossRef]

19. The Great Green Wall Implementation Status and Way Ahead to 2030. Advanced Version; United Nations Convention to Combat Desertification, Climatekos GmbH: Berlin, Germany, 2020. Available online: https://catalogue.unccd.int/1551_GGW_Report_ ENG_Final_040920.pdf (accessed on 14 January 2021).

20. Oni, P.I. State of Forest Genetic Resources in the Dry North of Nigeria; Forest Genetic Resources Working Papers 16E; Forest Resources Division FAO: Rome, Italy, 2001. Available online: http:/ / www.fao.org/3/ab392e/ab392e.pdf (accessed on 14 January 2021).

21. Ajayi, S.S.; Milligan, K.R.N.; Ayeni, J.S.O.; Afolayan, T.A. A management programme for Kwlambana Game Reserve, Sokoto State, Nigeria. Biol. Conserv. 1981, 20, 45-57. [CrossRef]

22. BirdLife International. Important Bird Areas Factsheet; Kamuku. 2021. Available online: http://www.birdlife.org (accessed on 25 January 2021).

23. Udo, R.K. Geographical Regions of Africa; Morrison and Gibb Ltd.: London, UK; Edinburgh, UK, 1970.

24. U.S. Geological Survey. Digital Elevation-Shuttle Radar Topography Mission (SRTM) 1 Arc-Second Global. Available online: https:/ / www.usgs.gov/centers/eros/science/usgs-eros-archive-digital-elevation-shuttle-radar-topography-mission-srtm-1 (accessed on 25 January 2021).

25. Schoeneich, K. Report on Result of Measurement of the Remaining Storage in Kubanni Impounding Reservoir and Proposal for Upgrading the Environment in Kubanni Drainage Basin; Unpublished Report; Ahmadu Bello University: Zaria, Nigeria, 2008.

26. Odihi, J. Deforestation in afforestation priority zone in Sudano-Sahelian Nigeria. Appl. Geogr. 2003, 23, 227-259. [CrossRef] 
27. Cline-Cole, R.; Maconachie, R. Wood energy interventions and development in Kano, Nigeria; A longitudinal, 'situated' perspective. Land Use Policy 2015, 52, 163-173. [CrossRef]

28. Baba, A. Integrated Water Resources Management Plan for Ahmadu Bello University. M.Sc. Report; The Department of Geology, Ahmadu Bello University: Zaria, Nigeria, 2008.

29. Google Earth Pro Inc. v. 7.3.4.8248. Available online: https:/ / earth.google.com/web/ (accessed on 17 January 2022).

30. U.S. Geological Survey. Earth Explorer, LE07_2000-04-28_Level 1C1, LC08_2020_04_27. Available online: https://earthexplorer. usgs.gov (accessed on 25 January 2021).

31. Tucker, C.J. Red and photographic infrared linear combinations for monitoring vegetation. Remote Sens. Environ. 1979, 8, 127-150. [CrossRef]

32. Myneni, R.B.; Hall, F.G.; Sellers, P.J.; Marshak, A.L. The interpretation of spectral vegetation indexes. IEEE Trans. Geosci. Remote Sens. 1995, 33, 481-486. [CrossRef]

33. Herrmann, S.M.; Anyamba, A.; Tucker, C.J. Recent trends in vegetation dynamics in the African Sahel and their relationship to climate. Glob. Environ. Chang. 2005, 15, 394-404. [CrossRef]

34. Ochege, F.U.; George, R.T.; Dike, E.C.; Okpala-Okaka, C. Geospatial assessment of vegetation status in Sagbama oilfield environment in the Niger Delta region, Nigeria. Egypt. J. Remote Sens. Space Sci. 2017, 20, 211-221. [CrossRef]

35. Townshend, J.R.G.; Justice, C.O. Analysis of the dynamics of African vegetation using the normalized difference vegetation index. Int. J. Remote Sens. 1986, 7, 1435-1445. [CrossRef]

36. Kaufman, Y.J.; Tanre, D. Atmospherically resistant vegetation index (ARVI) for EOS-MODIS. IEEE Trans. Geosci. Remote Sens. 1992, 30, 261-270. [CrossRef]

37. Haboudane, D.; Miller, J.R.; Pattey, E.; Zarco-Tejadad, P.J.; Strachan, I.B. Hyperspectral vegetation indices and novel algorithms for predicting green LAI of crop canopies: Modeling and validation in the context of precision agriculture. Remote Sens. Environ. 2004, 90, 337-352. [CrossRef]

38. Gu, Z.; Ju, W.; Li, L.; Li, D.; Liu, Y.; Fan, W. Using vegetation indices and texture measures to estimate vegetation fractional coverage (VFC) of planted and natural forests in Nanjing city, China. Adv. Space Res. 2013, 51, 1186-1194. [CrossRef]

39. Cochet, H. Agrarian dynamics, population growth and resource management, the case of Burundi. GeoJournal 2004, 60, 111-122. [CrossRef]

40. Alcamo, J.; Schaldach, R.; Koch, J.; Kölking, C.; Lapola, D.; Priess, J. Evaluation of an integrated land use change model including a scenario analysis of land use change for continental Africa. Environ. Model. Softw. 2011, 26, 1017-1027. [CrossRef]

41. Hall, C.; Dawson, T.P.; Macdiarmid, J.I.; Matthews, R.B.; Smith, P. The impact of population growth and climate change on food security in Africa, looking ahead to 2050. Int. J. Agric. Sustain. 2017, 15, 124-135. [CrossRef]

42. Gray, L.C. Is land being degraded? A multi-scale investigation of landscape change in southwestern Burkina Faso. Land Degrad. Dev. 1999, 10, 329-343. [CrossRef]

43. Blay, D.; Bonkoungou, E.; Chamshama, S.A.O.; Chikamai, B. Rehabilitation of Degraded Lands in Sub-Saharan Africa: Lessons Learned from Selected Case Studies; Forestry Research Network for Sub-Saharan Africa (Fornessa), International Union of Forest Research Organizations: Vienna, Austria, 2004. Available online: https:/ / fornis.net/node/249 (accessed on 15 January 2021).

44. Usman, B.A.; Adefalu, L.L. Nigerian forestry, wildlife and protected areas: Status report. Biodiversity 2010, 11, 54-62. [CrossRef]

45. Yiran, G.A.B.; Kusimi, J.M.; Kufogbe, S.K. A synthesis of remote sensing and local knowledge approaches in land degradation assessment in the Bawku East District, Ghana. Int. J. Appl. Earth Obs. Geoinf. 2012, 14, 204-213. [CrossRef]

46. Osemeobo, G.J. The Human Causes of Forest Depletion in Nigeria. Environ. Conserv. 1988, 15, 17-28. [CrossRef]

47. Gilruth, P.T.; Hutchinson, C.F. Assessing Deforestation in the Guinea highlands of West Africa using Remote Sensing. Photogramm. Eng. Remote Sens. 1990, 56, 1375-1382.

48. Pouliot, M.; Treue, T.; Obiri, B.D.; Ouedraogo, B. Deforestation and the limited contribution of forests to rural livelihoods in West Africa: Evidence from Burkina Faso and Ghana. Ambio 2012, 41, 738-750. [CrossRef] [PubMed]

49. Aubréville, A.M.A. The Disappearance of the Tropical Forests of Africa. Fire Ecol. 2013, 9, 3-13. [CrossRef]

50. Huber, S.; Fensholt, R.; Rasmussen, K. Water availability as the driver of vegetation dynamics in the African Sahel from 1982 to 2007. Glob. Planet. Chang. 2011, 76, 186-195. [CrossRef]

51. du Plessis, A. Water scarcity and other significant challenges for South Africa. In Freshwater Challenges of South Africa and Its Upper Vaal River Springer Water; Springer International Publishing: Zürich, Switzerland, 2017; pp. 119-127. [CrossRef]

52. Coulibaly, N.; Coulibaly, T.; Mpakama, Z.; Savané, I. The impact of climate change on water resource availability in a transboundary basin in West Africa, the case of Sassandra. Hydrology 2018, 5, 12. [CrossRef]

53. Igboanugo, A.B.I.; Omijeh, J.E.; Adegbehin, J.O. Pasture floristic composition in different Eucalyptus species plantations in some parts of northern Guinea savanna zone of Nigeria. Agrofor. Syst. 1990, 12, 257-268. [CrossRef]

54. Bayala, J.; Sanou, J.; Teklehaimanot, Z.; Kalinganire, A.; Ouédraogo, S.J. Parklands for buffering climate risk and sustaining agricultural production in the Sahel of West Africa. Curr. Opin. Environ. Sustain. 2014, 6, 28-34. [CrossRef]

55. Barau, A.S.; Kafi, K.M.; Sodangi, A.B.; Usman, S.G. Recreating African biophilic urbanism, the roles of millennials, native trees, and innovation labs in Nigeria. Cities Health 2020, 1-11. [CrossRef]

56. Tooth, S. Virtual globes: A catalyst for the re-enchantment of geomorphology? Earth Surf. Process. Landf. 2006, 31, 1192-1194. [CrossRef]

57. Boardman, B. The value of Google Earth ${ }^{\mathrm{TM}}$ for erosion mapping. Catena 2016, 143, 123-127. [CrossRef] 
58. Gilad, U.; Denham, R.; Tindall, D. Gullies, Google Earth and the Great Barrier Reef, a remote sensing methodology for mapping gullies over extensive areas. In Proceedings of the International Archives of the Photogrammetry, Remote Sensing and Spatial Information Science, XXII ISPRS Congress, Melbourne, Australia, 25 August-1 September 2012.

59. Malarvizhi, K.; Vasantha Kumar, S.; Porchelvan, P. Use of high resolution Google Earth satellite imagery in landuse map preparation for urban related applications. Procedia Technol. 2016, 24, 1835-1842. [CrossRef]

60. Liu, C.L.C.; Kuchma, O.; Krutovsky, K.V. Mixed-species versus monocultures in plantation forestry: Development, benefits, ecosystem services and perspectives for the future. Glob. Ecol. Conserv. 2018, 15, e00419. [CrossRef]

61. Jactel, H.; Menassieu, P.; Vetillard, F.; Gaulier, A.; Samalens, J.C. Tree species diversity reduces the invasibility of maritime pine stands by the bast scale, Matsucoccus feytaudi (Homoptera: Margarodidae). Can. J. For. Res. 2006, 36, 314-323. [CrossRef]

62. Thompson, I.D.; Okabe, K.; Parrotta, J.A.; Brockerhoff, E.; Jactel, H.; Forrester, D.I.; Taki, H. Biodiversity and ecosystem services, lessons from nature to improve management of planted forests for REDD-plus. Biodivers. Conserv. 2014, 23, 2613-2635. [CrossRef]

63. Lohbeck, M.; Bongers, F.; Martinez-Ramos, M.; Poorter, L. The importance of biodiversity and dominance for multiple ecosystem functions in a human-modified tropical landscape. Ecology 2016, 97, 2772-2779. [CrossRef]

64. Jactel, H.; Bauhus, J.; Boberg, J.; Bonal, D.; Castagneyrol, B.; Gardiner, B.; Gonzalez-Olabarria, J.R.; Koricheva, J.; Meurisse, N.; Brockerhoff, E.G. Tree diversity drives forest stand resistance to natural disturbances. Curr. For. Rep. 2017, 3, 223-243. [CrossRef]

65. Hérault, B.; N'Guessan, A.K.; Ouattara, N.; Ahoba, A.; Bénédet, F.; Coulibaly, B.; Louppe, D. The long-term performance of 35 tree species of sudanian West Africa in pure and mixed plantings. For. Ecol. Manag. 2020, 468, 118171. [CrossRef]

66. Keeley, J.E. Population variation in root grafting and a hypothesis. Oikos 1988, 52, 364. [CrossRef]

67. Brzeziecki, B. Biogrupy drzew w lesie naturalnym: Czy prof. Włoczewski miał rację? Sylwan 2004, 7, 3-10.

68. Quer, E.; Baldy, V.; DesRochers, A. Ecological drivers of root grafting in balsam fir natural stands. For. Ecol. Manag. 2020, 475, 118388. [CrossRef]

69. Oyewole, B.D.; Carsky, R.J. Multiple purpose tree use by farmers using indigenous knowledge in sub-humid and semiarid northern Nigeria. For. Trees Livelihoods 2001, 11, 295-312. [CrossRef]

70. Fifanou, V.G.; Ousmane, C.; Gauthier, B.; Brice, S. Traditional agroforestry systems and biodiversity conservation in Benin (West Africa). Agrofor. Syst. 2011, 82, 1-13. [CrossRef]

71. Ouédraogo-Koné, S.; Kaboré-Zoungrana, C.Y.; Ledin, I. Important characteristics of some browse species in an agrosilvopastoral system in West Africa. Agrofor. Syst. 2007, 74, 213-221. [CrossRef]

72. Usman, K. Analysis of Agro forestry Farmers (Tree-Planting) in Giwa Local Government Area, Kaduna State, Nigeria. Ph.D. Thesis, Ahmadu Bello University, Zaria, Nigeria, 2011. Available online: https:/ / www.semanticscholar.org/paper/ANALYSISOF-AGRO-FORESTRY-FARMERS-(TREE-PLANTING)-Usman/0341899e67e2e3e1c425292caa8a342b9c5793a1 (accessed on 10 January 2021).

73. Tenuche, M.S.; Ifatimehin, O.O. Resource conflict among farmers and Fulani herdsmen: Implications for resource sustainability. Afr. J. Pol. Sci. Int. Relat. 2009, 3, 360-364.

74. Halliru, S.L. Security implication of climate change between farmers and cattle rearers in Northern Nigeria: A case study of three communities in Kura Local Government of Kano State. In Handbook of Climate Change Adaptation; Leal, W., Ed.; Springer: Berlin/Heidelberg, Germany, 2015.

75. Dimelu, M.U.; Salifu, D.E.; Enwelu, A.I.; Igbokwe, E.M. Challenges of herdsmen-farmers' conflict in livestock production in Nigeria, Experience of pastoralists in Kogi State, Nigeria. Afr. J. Agric. Res. 2017, 8, 642-650. [CrossRef]

76. Awazi, N.P.; Avana-Tientcheu, M.-L. Agroforestry as a sustainable means to farmer-grazier conflict mitigation in Cameroon. Agrofor. Syst. 2020, 94, 2147-2165. [CrossRef] 